\title{
甘肃省森林碳储量现状与固碳速率
}

\author{
关晋宏 1,2 杜 盛 $1,3^{*}$ 程积民 吴春荣 $^{4}$ 李国庆 ${ }^{1,3}$ 邓 磊 $^{2}$ 张建国 $^{3}$ \\ 何秋月2 时伟宇 ${ }^{5}$
}

${ }^{1}$ 西北农林科技大学黄土高原土壤侵蚀与早地农业国家重点实验室, 陕西杨凌 $712100 ;{ }^{2}$ 西北农林科技大学林学院, 陕西杨凌 $712100 ;{ }^{3}$ 中国科学院水利部 水土保持研究所, 陕西杨凌 $712100 ;{ }^{4}$ 甘肃省治沙研究所, 兰州 $730000 ;{ }^{5}$ 中国科学院地球环境研究所黄土与第四纪地质国家重点实验室, 西安 710075

摘 要 针对森林碳平衡再评估的重要性和区域尺度森林生态系统碳库量化分配的不确定性, 该研究依据全国森林资源连 续清查结果中甘肃省各森林类型分布的面积与蓄积比重以及林龄和起源等要素, 在甘肃省布设 212 个样地, 经野外调查与采 样、室内分析, 并对典型样地信息按照面积权重进行尺度扩展, 估算了甘肃省森林生态系统碳储量及其分布特征。结果表明: 甘肃省森林生态系统总碳储量为612.43 Tg C, 其中植被生物量碳为 $179.04 \mathrm{Tg} \mathrm{C}$, 土壤碳为 $433.39 \mathrm{Tg} \mathrm{C}$ 。天然林是甘肃省碳储 量的主要贡献者, 其值为 $501.42 \mathrm{Tg} \mathrm{C}$, 是人工林的 4.52 倍。天然林和人工林的植被碳密度均表现为随林龄的增加而增加的趋 势, 同一龄组天然林植被碳密度高于人工林。天然林土壤碳密度从幼龄林到过熟林逐渐增加, 但人工林土壤碳密度最大值主 要为近熟林。全省森林植被碳密度均值为 $72.43 \mathrm{Mg} \mathrm{C} \cdot \mathrm{hm}^{-2}$, 天然林和人工林分别为 90.52 和 $33.79 \mathrm{Mg} \mathrm{C} \cdot \mathrm{hm}^{-2}$ 。基于森林清查资 料和标准样地实测数据, 估算出全省天然林和人工林在 1996 年的植被碳储量为 132.47 和 $12.81 \mathrm{Tg} \mathrm{C}, 2011$ 年分别为 152.41 和 $26.63 \mathrm{Tg} \mathrm{C}$, 平均固碳速率分别为 1.33 和 $0.92 \mathrm{Tg} \mathrm{C} \cdot \mathrm{a}^{-1}$ 。甘肃省幼、中龄林面积比重较大, 占全省的 $62.28 \%$, 根据碳密度随林龄 的动态变化特征, 预测这些低龄林将发挥巨大的碳汇潜力。

关键词 碳密度; 碳储量; 固碳速率; 森林生态系统; 甘肃省

引用格式: 关晋宏, 杜盛, 程积民, 吴春荣, 李国庆, 邓否, 张建国, 何秋月, 时伟宇 (2016). 甘肃省森林碳储量现状与固碳速率. 植物生态学报, 40, 304-317. doi: 10.17521/cjpe.2016.0017

\section{Current stocks and rate of sequestration of forest carbon in Gansu Province, China}

GUAN Jin-Hong ${ }^{1,2}$, DU Sheng ${ }^{1,3^{*}}$, CHENG Ji-Min ${ }^{1,3}$, WU Chun-Rong ${ }^{4}$, LI Guo-Qing ${ }^{1,3}$, DENG Lei ${ }^{2}$, ZHANG Jian-Guo ${ }^{3}, \mathrm{HE}$ Qiu-Yue ${ }^{2}$, and SHI Wei-Yu ${ }^{5}$

${ }^{1}$ State Key Laboratory of Soil Erosion and Dryland Farming on Loess Plateau, Northwest A \& F University, Yangling, Shaanxi 712100 , China; ${ }^{2}$ College of Forestry, Northwest A \& F University, Yangling, Shaanxi 712100, China; ${ }^{3}$ Institute of Soil and Water Conservation, Chinese Academy of Sciences and Ministry of Water Resources, Yangling, Shaanxi 712100, China; ${ }^{4}$ Gansu Desert Control Research Institute, Lanzhou 730000, China; and ${ }^{5}$ State Key Laboratory of Loess and Quaternary Geology, Institute of Earth Environment, Chinese Academy of Sciences, Xi'an 710075, China

\section{Abstract}

Aims Carbon sequestration is the basic function and most primary service of forest ecosystems, and plays a vital role in mitigating the global climate change. However, carbon storage and allocation in forest ecosystems have been less studied at regional scales than at forest stand levels, and the results are subject to uncertainty due to inconsistent methodologies. In this study we aim to obtain relatively accurate estimates of forest carbon stocks and sequestration rate at a provincial scale (regional) based on plot surveys of plants and soils.

Methods In consideration of the areas and distributions of major forest types, 212 sampling plots, covering different age classes and origins (natural forests vs. planted forests), were surveyed in Gansu Province in northern China. Field investigations were conducted for vegetation layers (trees, shrubs, herbs and litter), soil profiles, and sampling of both plant materials and soils for laboratory analyses. Regional carbon stocks were calculated by up-scaling the carbon densities of all forest types with their corresponding areas. Carbon sequestration rate was estimated by referencing the reports of national forest inventory data for different periods.

Important findings Forest carbon stocks at the provincial scale were estimated at $612.43 \mathrm{Tg} \mathrm{C}$, including 179.04 $\mathrm{Tg} \mathrm{C}$ in biomass and 433.39 Tg C in soil organic materials. Specifically, natural forests stored 501.42 Tg C, approximately 4.52 times than that of the plantations. Biomass carbon density in both natural forests and plantations showed an increasing trend with stand age classes, and was greater in natural forests than in plantations within the

收稿日期Received: 2016-01-12 接受日期Accepted: 2016-03-30

* 通信作者Author for correspondence (E-mail: shengdu@ms.iswc.ac.cn) 
same age classes. Soil carbon density also increased with stand age classes in natural forests, but the highest value occurred at the pre-mature stage in plantations. The weighted average of regional biomass carbon density was at $72.43 \mathrm{Mg} \mathrm{C} \cdot \mathrm{hm}^{-2}$, with the average value of $90.52 \mathrm{Mg} \mathrm{C} \cdot \mathrm{hm}^{-2}$ in natural forests and $33.79 \mathrm{Mg} \mathrm{C} \cdot \mathrm{hm}^{-2}$ in plantations, respectively. In 1996, vegetation stored $132.47 \mathrm{Tg} \mathrm{C}$ in natural forests and $12.81 \mathrm{Tg} \mathrm{C}$ in plantations, respectively, and the values increased to 152.41 and $26.63 \mathrm{Tg} \mathrm{C}$ in 2011, with the mean carbon sequestration rates of 1.33 and $0.92 \mathrm{Tg} \mathrm{C} \cdot \mathrm{a}^{-1}$. Given that young and middle-aged forests account for a large proportion $(62.28 \%)$ of the total forest areas, the region is expected to have substantial potential of carbon sequestration.

Key words carbon density; carbon storage; carbon sequestration rate; forest ecosystem; Gansu Province

Citation: Guan JH, Du S, Cheng JM, Wu CR, Li GQ, Deng L, Zhang JG, He QY, Shi WY (2016). Current stocks and rate of sequestration of forest carbon in Gansu Province, China. Chinese Journal of Plant Ecology, 40, 304-317. doi: 10.17521/cjpe.2016.0017

森林作为陆地生态系统的主体，储存了 $80 \%$ 的 地上碳储量和 $40 \%$ 的地下碳储量, 在维持全球碳平 衡减缓气候变化中发挥着重要作用, 因此, 森林碳 固存已成为全球碳循环研究的热点(Dixon et al., 1994; Houghton, 2005)。科学估测森林生态系统碳密 度、碳储量及其变化特征是充分认识森林生态系统 功能、评价区域森林碳汇潜力和应对气候变化的首 要任务。

近年来, 国内外学者采用多种研究手段, 针对 不同目标, 从林分(Ren et al., 2010; Zhang et al., 2013b)、区域(Chen et al., 2009; Zhang et al., 2012)、 国家(Fang et al., 2001; Zhang et al., 2013a)及全球尺 度上(Houghton, 2005)对森林生态系统碳密度及碳 储量进行了研究报道, 揭示了不同气候条件下多种 森林类型的固碳现状及其动态变化。例如, Fang等 (2001)和方精云等(2007)基于生物量转化因子连续 函数法估算出我国森林植被碳储量在1998和2000年 分别为4.75和5.85 Pg C; 李海奎等(2011)用回归模 型估算法得出 2006 年我国森林植被碳储量为 7.81 Pg C。其他学者也在不同时期深化研究了海南(Ren et al., 2014)、广东(Ren et al., 2013)、吉林(王新闯等, 2011)、四川(黄从德等, 2008b)、陕西(崔高阳等, 2015)、宁夏(高阳等, 2014)等区域尺度的森林生态系 统碳库及其分配特征。然而, 由于我国气候带跨越热 带至寒温带, 涵盖从温润至干旱各个气候区, 森林 生态系统类型复杂多样, 导致植被和土壤碳积累过 程呈现区域性差异, 加之研究方法不同, 造成估算 结果存在较大误差(刘世荣等, 2011)。因此, 方法同一 化、时间同步化地估测区域尺度森林生态系统碳汇 及分配特征是探明我国森林碳汇现状的先决条件。

甘肃省作为西部欠发达省份和生态脆弱地区, 森林覆盖率在全国排第18位(徐济德, 2014)。但由于
特殊的地形气候特征, 甘肃省也是我国森林植被类 型比较复杂的省区之一, 森林植被有北亚热带常 绿、落叶阔叶林, 暖温带针叶、阔叶林, 寒温带(山 地)针叶林等多种类型, 在气候调节、水源涵养、水 土保持、生物多样性保护以及碳固存等方面起着不 可估量的作用。联合国反荒漠化大会认为半干旱区 森林及土壤在恰当的管理下可发挥显著的碳汇作用 (彭少麟等, 2002)。迄今为止, 针对甘肃省森林生态 系统碳密度及碳储量的报道仅见于个别树种(程堂 仁等, 2007b; 彭守璋等，2011)、林区(程堂仁等, 2007a)及区域尺度活立木的简单估算(彭焕华等, 2010; Guan et al., 2015), 而区域尺度上森林生态系 统固碳特征尚不清楚, 尤其缺乏林下植被层及土壤 碳的信息。本文以甘肃省整个区域尺度主要森林生 态系统为研究对象, 在样地调查和室内分析的基础 上, 分析各森林类型碳密度特征, 并结合 1996 、 2001、2006和2011年4次森林资源连续清查资料, 估 算全省碳储量现状和固碳速率。研究结果可为森林 生态系统碳汇功能评价及可能开展的碳汇交易提供 参考依据。

\section{1 研究区域和研究方法}

\section{1 研究区概况}

甘肃省位于我国西北部 $\left(32.18^{\circ}-42.95^{\circ} \mathrm{N}\right.$, $92.22^{\circ}-108.77^{\circ} \mathrm{E}$ ), 地处黄河上游地区, 自西北向东 南狭长约 $1350 \mathrm{~km}$, 面积为 $45.3 \times 10^{4} \mathrm{~km}^{2}$, 占国土 总面积的 $4.7 \%$ 。甘肃省具有明显的温带季风气候, 冬季寒冷漫长, 夏季短促温热。省内地区间气候差 异巨大, 年平均气温在0-10 ${ }^{\circ} \mathrm{C}$, 年降水量36.6$734.9 \mathrm{~mm}$, 降水主要集中在6-9月, 由东南向西北 递减。气候从东南向西北也呈现序列性变化: 陇南 山地北部的暖温带湿润气候、陇中黄土高原的温带 
半湿润和半干旱气候、河西走廊温带干旱气候和北 山极干旱气候。受水热条件交互作用, 甘肃省森林 植被类型丰富多样，分布有亚热带常绿阔林带、暖 温带落叶阔叶林带、温带草原带和温带荒漠带。

据《第八次全国森林资源清查甘肃省森林资源 清查成果》 ${ }^{(1)}$, 甘肃省现有森林 ${ }^{2}$ 面积 $507.45 \times 10^{4}$ $\mathrm{hm}^{2}$, 森林覆盖率 $11.28 \%$ (徐济德, 2014)。其中, 乔 木林面积和蓄积量分别为 $247.19 \times 10^{4} \mathrm{hm}^{2}$ 和 214.54 $\times 10^{6} \mathrm{~m}^{3}$ 。甘肃省中南部和东部分布有多个典型森 林的国有林区，例如小陇山林区、白龙江林区、子 午岭林区等; 也有白水江(南部)、太子山(中部)、祁 连山(西北部)等多个以森林为主的自然保护区。甘 肃全省天然林比重较大，面积和蓄积分别为 168.38 $\times 10^{4} \mathrm{hm}^{2}$ 和 $186.22 \times 10^{6} \mathrm{~m}^{3}$, 占全省的 $68.12 \%$ 和 $86.80 \%$ 。天然林中面积最大的为中龄林，占 $33.15 \%$ 。 天然林类型主要以栎类(Quercus spp.)、阔叶混交林 (broad-leaved mixed forest)、云杉(Picea asperata)林、 冷杉(Abies fabri)林为主, 面积和蓄积分别占天然林 的 $59.54 \%$ 和 $72.60 \%$ 。人工林中以幼龄林居多, 占人 工林面积的 $61.64 \%$ 。人工阔叶林主要以杨树 (Populus spp.)林和刺槐(Robinia pseudoacacia)林为 主, 面积和蓄积分别占全省人工林的 $56.45 \%$ 和 $63.79 \%$; 人工针叶林以云杉林、落叶松 (Larix gmelinii)林、油松(Pinus tabuliformis)林为主, 面积和 蓄积分别占全省人工林的 $19.50 \%$ 和 $21.37 \%$ 。

\section{2 研究方法}

\subsection{1 样地设置及取样方法}

本研究依托中国科学院战略性先导科技专项 (碳专项), 按照《生态系统固碳现状、速率、机制和 潜力》项目制定的统一要求(生态系统固碳项目技术 规范编写组, 2015), 并结合甘肃省第七次森林资源 清查成果, 充分考虑全省各森林类型(优势种)分布 面积与蓄积比重、林龄、起源等情况, 在全省布设 涵盖该省 17 种主要森林类型的标准地 212 个(表1)。 样地面积设置标准为 $20 \mathrm{~m} \times 50 \mathrm{~m}$, 但因地形破碎及 林分面积限制, 部分标准地设置为 $20 \mathrm{~m} \times 30 \mathrm{~m}$ 。其 中, 铁杉(Tsuga chinensis)没有布设相应样地, 以云 杉、冷杉和柏木(Cupressus funebris)的加权平均值来

(1) 国家林业局西北森林资源监测中心, 甘肃省林业厅, 甘肃省林业调查 规划院 (2012). 《第八次全国森林资源清查甘肃省森林资源清查成果》. (2) 该森林面积数据包括了国家特别规定的灌木林和竹林面积。本文研 究的森林为乔木林。

(3) 森林固碳课题办公室 (2014). 中国森林生态系统固碳现状、速率、 机制和潜力课题《生物量估算方程》。
求得该类森林生态系统各组分碳密度。本研究涉及 的柇类主要包括锐齿桷柇 (Quercus aliena var. acuteserrata)、辽东栋(Quercus wutaishanica)、栓皮 栋(Quercus variabilis)等栋属优势树种; 杨树主要包 括山杨(Populus davidiana)、新疆杨(Populus alba var. pyramidalis)、二白杨(Populus gansuensis)等; 桦 木主要包括红桦(Betula albosinensis)和白桦(Betula platyphylla)。

本研究各森林类型包括幼龄林、中龄林、近熟 林、成熟林和过熟林 5 个龄组。不同森林类型生长速 度及其寿命因树种、起源而异, 各龄组的划分标准 不一, 具体见表 2 。此外, 本研究各项野外调查、样 品采集、成分分析均依据《生态系统固碳现状、速 率、机制和潜力》项目制定的统一标准(生态系统固 碳项目技术规范编写组, 2015)展开。

\subsection{2 乔木层碳密度测定}

对样地内所有胸径 $\geqslant 2 \mathrm{~cm}$ 的乔木进行每木检 尺, 并记录地形、地貌、经营管理措施等因子。样 地内乔木单株生物量通过每木检尺所测的胸径和树 高结合异速生长方程求得。按大、中、小径级选择3-5 株样木, 采集样地内优势乔木树种各器官(叶、枝、 干、根)样品各 $300 \mathrm{~g}$, 用以有机碳含量分析。利用分 析测定乔木层各器官的有机碳含量分别乘以各自的 单位面积生物量, 对其求和即为乔木层碳密度。对 异速生长方程的选择则以地形、气候条件等相近的 优势树种为篮选原则, 对所选方程进行模拟, 选出 适合该省区优势树种的最优方程(表3)。其中，其他 硬阔类指鹅耳枥(Carpinus turczaninowii)、千金榆 (Carpinus cordata)、椴树(Tilia spp.)、华榛(Corylus chinensis) 等; 其他软阔类指白蜡(Fraxinus chinensis)、青榨槭(Acer davidii)、稠梨(Padus racemosa)、 漆(Toxicodendron vernicifluum) 等。树种 $1 、 2 、 3 、 5 、$ $6 、 7 、 8$ 和 11 生物量方程来源于程堂仁等(2007a), 树 种4、9、10和12生物量方程由森林固碳课题办公室 提供 ${ }^{3}$ 。

\subsection{3 林下植被层、枯落物层碳密度测定}

林下植被包括灌木、草本和胸径 $<2 \mathrm{~cm}$ 的幼树。 在上述样地内沿对角线设置 3 个 $2 \mathrm{~m} \times 2 \mathrm{~m}$ 的灌木小 样方, 并在每个灌木样方内设置 1 个 $1 \mathrm{~m} \times 1 \mathrm{~m}$ 的草 本小样方, 采用全收获法对灌木和草本进行采集。 全收获后, 灌木按叶、枝和根测定其生物量鲜质量, 草本分地上部分和地下部分测定其生物量鲜质量,

www.plant-ecology.com 
表1 甘肃省样地信息表

Table 1 General information of survey plots in Gansu Province

\begin{tabular}{|c|c|c|c|c|c|c|c|}
\hline \multirow{2}{*}{$\begin{array}{l}\text { 森林类型 } \\
\text { Forest type }\end{array}$} & \multirow{2}{*}{$\begin{array}{l}\text { 森林起源 } \\
\text { Forest origin }\end{array}$} & \multirow{2}{*}{$\begin{array}{l}\text { 林龄组 } \\
\text { Forest age group }\end{array}$} & \multirow{2}{*}{$\begin{array}{l}\text { 样地数量 } \\
\text { Number of } \\
\text { plots }\end{array}$} & \multirow{2}{*}{$\begin{array}{l}\text { 样地分布区 } \\
\text { Plot location }\end{array}$} & \multirow{2}{*}{$\begin{array}{l}\text { 主要土壤类型 } \\
\text { Main soil types }\end{array}$} & \multicolumn{2}{|c|}{ 土壤取样 Soil sampling } \\
\hline & & & & & & $\begin{array}{c}\text { 取样深度 } \\
\text { Sampling } \\
\text { Depth (cm) }\end{array}$ & $\begin{array}{c}\text { 样地数量 } \\
\text { Number of } \\
\text { plots }\end{array}$ \\
\hline \multirow{3}{*}{$\begin{array}{l}\text { 冷杉 } \\
\text { Abies fabri }\end{array}$} & 天然林 & 幼、中、成、过 & 13 & 甘南 & 山地棕壤、山地褐土、山地灰褐土 & $0-50$ & 3 \\
\hline & Natural forest & $\begin{array}{l}\text { YF, MAF, MF and } \\
\text { OMF }\end{array}$ & & Gannan & $\begin{array}{l}\text { Mountainous brown earths, moun- } \\
\text { tainous cinnamon soils, and moun- } \\
\text { tainous grey cinnamon soils }\end{array}$ & $0-100$ & 10 \\
\hline & $\begin{array}{l}\text { 人工林 } \\
\text { Plantation }\end{array}$ & - & - & - & - & - & - \\
\hline \multirow{4}{*}{$\begin{array}{l}\text { 云杉 } \\
\text { Picea asperata }\end{array}$} & 天然林 & 幼、中、近、成、 & 32 & 甘南、定西、张掖、兰州、 & 山地棕壤、山地褐土、山地灰褐土 & $0-30$ & 1 \\
\hline & Natural forest & $\begin{array}{l}\text { 过 } \\
\text { YF, MAF, PMF, } \\
\text { MF and OMF }\end{array}$ & & $\begin{array}{l}\text { 武威 } \\
\text { Gannan, Dingxi, Zhangye, } \\
\text { Lanzhou, and Wuwei }\end{array}$ & $\begin{array}{l}\text { Mountainous brown earths, moutain- } \\
\text { ous cinnamon soils, and mountainous } \\
\text { grey cinnamon soils }\end{array}$ & $0-100$ & 31 \\
\hline & 人工林 & 幼、中、近、成 & 16 & 甘南、定西 & 山地棕壤、山地褐土、黄绵土 & $0-30$ & 2 \\
\hline & Plantation & $\begin{array}{l}\text { YF, MAF, PMF and } \\
\text { MF }\end{array}$ & & Gannan and Dingxi & $\begin{array}{l}\text { Mountainous brown earths, moutainous } \\
\text { cinnamon soils, and cultivated loess }\end{array}$ & $0-100$ & 14 \\
\hline \multirow{3}{*}{$\begin{array}{l}\text { 油松 } \\
\text { Pinus } \\
\text { tabulaeformis }\end{array}$} & 天然林 & 中、成 & 4 & 陇南、庆阳 & 山地褐土、黄绵土Mountainous & $0-100$ & 4 \\
\hline & Natural forest & $\mathrm{MAF}$ and MF & & Longnan and Qingyang & cinnamon soils and cultivated loess & & \\
\hline & $\begin{array}{l}\text { 人工林 } \\
\text { Plantation }\end{array}$ & $\begin{array}{l}\text { 幼、中、近、成 } \\
\text { YF, MAF, PMF and } \\
\text { MF }\end{array}$ & 20 & $\begin{array}{l}\text { 临夏、陇南、庆阳、定西、 } \\
\text { 兰州 } \\
\text { Linxia, Longnan, Qing- } \\
\text { yang, Dingxi, and Lanzhou }\end{array}$ & $\begin{array}{l}\text { 山地灰褐土、黄绵土、山地棕壤 } \\
\text { Mountainous grey cinnamon soils, } \\
\text { cultivated loess, and mountainous } \\
\text { brown earths }\end{array}$ & $0-100$ & 20 \\
\hline \multirow{3}{*}{$\begin{array}{l}\text { 华山松 } \\
\text { Pinus } \\
\text { armandii }\end{array}$} & 天然林 & 近 & 1 & 天水 & 山地褐土 & $0-100$ & 1 \\
\hline & Natural forest & PMF & & Tianshui & Mountainous cinnamon soils & & \\
\hline & $\begin{array}{l}\text { 人工林 } \\
\text { Plantation }\end{array}$ & $\begin{array}{l}\text { 近 } \\
\text { PMF }\end{array}$ & 3 & $\begin{array}{l}\text { 陇南、天水 } \\
\text { Longnan and Tianshui }\end{array}$ & $\begin{array}{l}\text { 山地棕壤、山地褐土 } \\
\text { Mountainous brown earths and moun- } \\
\text { tainous cinnamon soils }\end{array}$ & $0-100$ & 3 \\
\hline \multirow{2}{*}{$\begin{array}{l}\text { 落叶松 } \\
\text { Larix } \\
\text { gmelinii }\end{array}$} & 天然林 & - & - & - & - & - & - \\
\hline & $\begin{array}{l}\text { Natural forest } \\
\text { 人工林 } \\
\text { Plantation }\end{array}$ & $\begin{array}{l}\text { 幼、中、近、成 } \\
\text { YF, MAF, PMF and } \\
\text { MF }\end{array}$ & 12 & $\begin{array}{l}\text { 甘南、陇南、天水、定西 } \\
\text { Gannan, Longnan, } \\
\text { Tianshui, and Dingxi }\end{array}$ & $\begin{array}{l}\text { 山地棕壤、山地褐土 } \\
\text { Mountainous brown earths and moun- } \\
\text { tainous cinnamon soils }\end{array}$ & $0-100$ & 12 \\
\hline \multirow{2}{*}{$\begin{array}{l}\text { 柏木 } \\
\text { Cupressus } \\
\text { funebris }\end{array}$} & $\begin{array}{l}\text { 天然林 } \\
\text { Natural forest }\end{array}$ & $\begin{array}{l}\text { 中 } \\
\mathrm{MAF}\end{array}$ & 6 & $\begin{array}{l}\text { 武威 } \\
\text { Wuwei }\end{array}$ & $\begin{array}{l}\text { 山地灰褐土 } \\
\text { Mountainous grey cinnamon soils }\end{array}$ & $0-100$ & 6 \\
\hline & $\begin{array}{l}\text { 人工林 } \\
\text { Plantation }\end{array}$ & - & - & - & - & - & - \\
\hline \multirow{4}{*}{$\begin{array}{l}\text { 栋类 } \\
\text { Quercus spp. }\end{array}$} & 天然林 & 幼、中、近、成 & 22 & 陇南、天水、庆阳 & 山地褐土、山地棕壤 & $0-30$ & 1 \\
\hline & Natural forest & $\begin{array}{l}\text { YF, MAF, PMF and } \\
\text { MF }\end{array}$ & & $\begin{array}{l}\text { Longnan, Tianshui, and } \\
\text { Qingyang }\end{array}$ & $\begin{array}{l}\text { Mountainous cinnamon soils and } \\
\text { mountainous brown earths }\end{array}$ & $0-50$ & 2 \\
\hline & & & & & & $0-100$ & 19 \\
\hline & $\begin{array}{l}\text { 人工林 } \\
\text { Plantation }\end{array}$ & - & - & - & - & - & - \\
\hline \multirow{4}{*}{$\begin{array}{l}\text { 杨树 } \\
\text { Populus spp. }\end{array}$} & 天然林 & 近、成 & 3 & 庆阳 & 黄褐土 & $0-100$ & 3 \\
\hline & Natural forest & PMF and MF & & Qingyang & Yellow cinnamon soils & & \\
\hline & 人工林 & 幼、中、近、过 & 29 & 酒泉、金昌、张掖、武威、 & 灰褐土、灌淤土、草甸土 & $0-50$ & 2 \\
\hline & Plantation & $\begin{array}{l}\text { YF, MAF, PMF and } \\
\text { OMF }\end{array}$ & & $\begin{array}{l}\text { 兰州、白银 } \\
\text { Jiuquan, Jinchang, Zhang- } \\
\text { ye, Wuwei, and Lanzhou }\end{array}$ & $\begin{array}{l}\text { Grey cinnamon soils, irrigation sedi- } \\
\text { ments, and meadow soils }\end{array}$ & $0-100$ & 27 \\
\hline \multirow{3}{*}{$\begin{array}{l}\text { 桦木 } \\
\text { Betula spp. }\end{array}$} & 天然林 & 幼、中 & 6 & 甘南、天水、庆阳 & 山地褐土、黄绵土 & $0-100$ & 6 \\
\hline & Natural forest & $\mathrm{YF}$ and MAF & & $\begin{array}{l}\text { Gannan, Tianshui, and } \\
\text { Qingyang }\end{array}$ & $\begin{array}{l}\text { Mountainous cinnamon soils and } \\
\text { cultivated loess }\end{array}$ & & \\
\hline & $\begin{array}{l}\text { 人工林 } \\
\text { Plantation }\end{array}$ & - & - & - & - & - & - \\
\hline \multirow{3}{*}{$\begin{array}{l}\text { 刺槐 } \\
\text { Robinia } \\
\text { pseudoacacia }\end{array}$} & 天然林 & - & - & - & - & - & - \\
\hline & Natural forest & & & & & & \\
\hline & $\begin{array}{l}\text { 人工林 } \\
\text { Plantation }\end{array}$ & $\begin{array}{l}\text { 幼、中、近、成 } \\
\text { YF, MAF, PMF and } \\
\text { MF }\end{array}$ & 15 & $\begin{array}{l}\text { 平凉、庆阳、白银 } \\
\text { Pingliang, Qingyang, and } \\
\text { Baiyin }\end{array}$ & $\begin{array}{l}\text { 黄绵土、灰褐土 } \\
\text { Cultivated loess and grey cinnamon } \\
\text { soils }\end{array}$ & $0-100$ & 15 \\
\hline \multirow{2}{*}{$\begin{array}{l}\text { 阔叶混交林 } \\
\text { Broad-leaved } \\
\text { mixed forest }\end{array}$} & 天然林 & - & - & - & - & - & - \\
\hline & $\begin{array}{l}\text { Natural forest } \\
\text { 人工林 } \\
\text { Plantation }\end{array}$ & $\begin{array}{l}\text { 幼 } \\
\mathrm{YF}\end{array}$ & 2 & $\begin{array}{l}\text { 张掖、兰州 } \\
\text { Zhangye and Lanzhou }\end{array}$ & $\begin{array}{l}\text { 灌淤土 } \\
\text { Irrigation sediments }\end{array}$ & $0-100$ & 2 \\
\hline \multirow[b]{2}{*}{$\begin{array}{l}\text { 针叶混父林 } \\
\text { Coniferous- } \\
\text { mixed forest }\end{array}$} & 天然林 & 中、成 & 2 & 天水 & 黄棕壤 & $0-100$ & 2 \\
\hline & $\begin{array}{l}\text { Natural forest } \\
\text { 人工林 } \\
\text { Plantation }\end{array}$ & $\begin{array}{l}\text { MAF and MF } \\
\text { 幼、成 } \\
\text { YF and MF }\end{array}$ & 2 & $\begin{array}{l}\text { Tianshui } \\
\text { 陇南、兰州 } \\
\text { Longnan and Lanzhou }\end{array}$ & $\begin{array}{l}\text { Yellow brown earths } \\
\text { 山地褐土、灌淤土 } \\
\text { Mountainous cinnamon soils and irriga- } \\
\text { tion sediments }\end{array}$ & $0-50$ & 2 \\
\hline
\end{tabular}


表1 (续) Table 1 (continued)

\begin{tabular}{|c|c|c|c|c|c|c|c|}
\hline \multirow{2}{*}{$\begin{array}{l}\text { 森林类型 } \\
\text { Forest type }\end{array}$} & \multirow{2}{*}{$\begin{array}{l}\text { 森林起源 } \\
\text { Forest origin }\end{array}$} & \multirow{2}{*}{$\begin{array}{l}\text { 林龄组 } \\
\text { Forest age group }\end{array}$} & \multirow{2}{*}{$\begin{array}{l}\text { 样地数量 } \\
\text { Number of } \\
\text { plots }\end{array}$} & \multirow{2}{*}{$\begin{array}{l}\text { 样地分布区 } \\
\text { Plot location }\end{array}$} & \multirow{2}{*}{$\begin{array}{l}\text { 主要土壤类型 } \\
\text { Main soil types }\end{array}$} & \multicolumn{2}{|c|}{ 土壤取样 Soil sampling } \\
\hline & & & & & & $\begin{array}{c}\text { 取样深度 } \\
\text { Sampling } \\
\text { Depth }(\mathrm{cm})\end{array}$ & $\begin{array}{c}\text { 样地数量 } \\
\text { Number of } \\
\text { plots }\end{array}$ \\
\hline 针阔混交林 & 天然林 & 幼、中、近 & 23 & 甘南、天水、陇南、庆阳 & 山地褐土、黄褐土、黄棕壤 & $0-30$ & 1 \\
\hline $\begin{array}{l}\text { Coniferous and } \\
\text { broad-leaved } \\
\text { mixed forest }\end{array}$ & Natural forest & YF, MAF and PMF & & $\begin{array}{l}\text { Gannan, Tianshui, Long- } \\
\text { nan, and Qingyang }\end{array}$ & $\begin{array}{l}\text { Mountainous cinnamon soils, yellow } \\
\text { cinnamon soils, and yellow brown } \\
\text { earths }\end{array}$ & $0-100$ & 22 \\
\hline & 人工林 & 中 & 1 & 天水 & 山地褐土 & $0-100$ & 1 \\
\hline & Plantation & MAF & & Tianshui & Mountainous cinnamon soils & & \\
\hline 合计 & 天然林 & 112 & & & & & \\
\hline Total & Natural forest & & & & & & \\
\hline & $\begin{array}{l}\text { 人工林 } \\
\text { Plantation }\end{array}$ & 100 & & & & & \\
\hline
\end{tabular}

表中幼、中、近、成和过分别指幼龄林、中龄林、近熟林、成熟林和过熟林。

YF, MAF, PMF, MF and OMF refer to young forest, middle-aged forest, pre-mature forest, mature forest and over-mature forest, respectively.

表2 甘肃省主要森林类型林龄组划分标准 ${ }^{(4}$

Table 2 Criteria of forest age group classification for major forest types in Gansu Province

\begin{tabular}{|c|c|c|c|c|c|c|}
\hline \multirow{2}{*}{$\begin{array}{l}\text { 森林类型 } \\
\text { Forest type }\end{array}$} & \multirow{2}{*}{$\begin{array}{l}\text { 森林起源 } \\
\text { Forest origin }\end{array}$} & \multicolumn{5}{|c|}{ 林龄组 Forest age group } \\
\hline & & $\begin{array}{l}\text { 幼龄林 } \\
\text { Young } \\
\text { forest }\end{array}$ & $\begin{array}{c}\text { 中龄林 } \\
\text { Middle- } \\
\text { aged forest }\end{array}$ & $\begin{array}{c}\text { 近熟林 } \\
\text { Pre-mature } \\
\text { forest }\end{array}$ & $\begin{array}{c}\text { 成熟林 } \\
\text { Mature } \\
\text { forest }\end{array}$ & $\begin{array}{c}\text { 过熟林 } \\
\text { Over-mature } \\
\text { forest }\end{array}$ \\
\hline \multirow{2}{*}{$\begin{array}{l}\text { 冷杉、柏木 } \\
\text { Abies fabri and Cupressus funebris }\end{array}$} & 天然林 Natural forest & $\leqslant 60$ & $61-100$ & $101-120$ & $121-160$ & $\geqslant 161$ \\
\hline & 人工林 Plantation & $\leqslant 40$ & $41-60$ & $61-80$ & $81-120$ & $\geqslant 121$ \\
\hline \multirow{2}{*}{$\begin{array}{l}\text { 云杉 } \\
\text { Picea asperata }\end{array}$} & 天然林 Natural forest & $\leqslant 40$ & $41-80$ & $81-100$ & $101-140$ & $\geqslant 141$ \\
\hline & 人工林 Plantation & $\leqslant 20$ & $21-30$ & $31-40$ & $41-60$ & $\geqslant 61$ \\
\hline \multirow{2}{*}{$\begin{array}{l}\text { 油松、华山松、落叶松 } \\
\text { Pinus tabulaeformis, Pinus armandii and Larix gmelinii }\end{array}$} & 天然林 Natural forest & $\leqslant 30$ & $31-50$ & $51-60$ & $61-80$ & $\geqslant 81$ \\
\hline & 人工林 Plantation & $\leqslant 20$ & $21-30$ & $31-40$ & $41-60$ & $\geqslant 61$ \\
\hline \multirow{2}{*}{$\begin{array}{l}\text { 杨、白桦、其他软阔类 } \\
\text { Populus spp., Betula platyphylla and other soft broad-leaved species }\end{array}$} & 天然林 Natural forest & $\leqslant 20$ & $21-30$ & $31-40$ & $41-60$ & $\geqslant 61$ \\
\hline & 人工林 Plantation & $\leqslant 10$ & $11-15$ & $16-20$ & $21-30$ & $\geqslant 31$ \\
\hline \multirow{2}{*}{$\begin{array}{l}\text { 刺槐、红桦 } \\
\text { Robinia pseudoacacia and Betula albosinensis }\end{array}$} & 天然林 Natural forest & $\leqslant 30$ & $31-50$ & $51-60$ & $61-80$ & $\geqslant 81$ \\
\hline & 人工林 Plantation & $\leqslant 20$ & $21-30$ & $31-40$ & $41-60$ & $\geqslant 61$ \\
\hline \multirow{2}{*}{$\begin{array}{l}\text { 栋类、其他硬阔类 } \\
\text { Quercus spp. and other hard broad-leaved species }\end{array}$} & 天然林 Natural forest & $\leqslant 40$ & $41-60$ & $61-80$ & $81-120$ & $\geqslant 121$ \\
\hline & 人工林 Plantation & $\leqslant 20$ & $21-40$ & $41-50$ & $51-70$ & $\geqslant 71$ \\
\hline
\end{tabular}

并分别取约 $300 \mathrm{~g}$ 用于含水率和有机碳含量的测定。 在各样地内沿对角线设置 3 个 $1 \mathrm{~m} \times 1 \mathrm{~m}$ 的枯落物小 样方,收集所有枯落物并称其鲜质量，保留约 $300 \mathrm{~g}$ 测定其含水率和有机碳含量。林下植被层和枯落物 层生物量根据各器官含水率换算为其干质量并分别 乘以各器官对应的有机碳含量求得相应的碳密度。

\subsection{4 土壤碳密度测定}

在调查样地周围选择未受人为干扰、植被结构 和土壤具代表性的地段, 挖掘土壤剖面, 每层取 2 个 重复, 不够 $100 \mathrm{~cm}$ 的土壤剖面以实际深度计算。按 照0-10 cm、10-20 cm、20-30 cm、30-50 cm、50-100 $\mathrm{cm}$ 不同深度, 用环刀采集各层土壤后带回实验室 $105{ }^{\circ} \mathrm{C}$ 烘干 $24 \mathrm{~h}$ 至恒质量, 计算各土层土壤容重。从

(4) 甘肃省林业厅 (2012). 甘肃省林地落界实施细则.
环刀内拣出 $>2 \mathrm{~mm}$ 以上的砾石, 洗净、烘干称质量。 同时，在每个草本样方内按 $0-10 \mathrm{~cm} 、 10-20 \mathrm{~cm}$ 、 20-30 cm、30-50 cm、50-100 cm 取样，将同一层土 壤样品按质量比例混合，带回实验室尽早进行处理， 拣出砾石、植物根系等杂物，自然风干、磨碎、过 篎, 用重铬酸钾硫酸氧化法测定土壤有机碳含量。 土壤各层有机碳密度结合土壤各层容重、有机碳含 量、砾石含量、土层深度求得, 各层碳密度相加即 为 $0-100 \mathrm{~cm}$ 土壤有机碳密度。

土壤有机碳密度(soil organic carbon density, $S O C D, \mathrm{Mg} \mathrm{C}^{-\mathrm{hm}^{-2}}$ )计算公式为:

$$
S O C D=\sum_{i=1}^{n}\left(C_{i} \times B D_{i} \times D_{i}\right) \times\left(1-R_{i} / 100\right) / 10
$$

式中: $C_{i}$ 为第 $i$ 层土壤有机碳含量 $\left(\mathrm{g} \cdot \mathrm{kg}^{-1}\right) ; B D_{i}$ 为该层 土壤平均容重 $\left(\mathrm{g} \cdot \mathrm{cm}^{-3}\right) ; D_{i}$ 为该层土壤厚度 $(\mathrm{cm}), R_{i}$ 为

www.plant-ecology.com 
表3 甘肃省主要优势树种及主要伴生树种生物量方程

Table 3 Biomass equation of dominant and associate tree species in Gansu Province

\begin{tabular}{|c|c|c|c|c|c|}
\hline 树种 Tree species & 干 $\operatorname{Stem}\left(\mathrm{kg} \cdot\right.$ ind $\left.^{-1}\right)$ & 枝 Branch $\left(\mathrm{kg} \cdot\right.$ ind..$\left.^{-1}\right)$ & 叶 Leaves $\left(\mathrm{kg} \cdot\right.$ ind. $\left.^{-1}\right)$ & 根 Roots $\left(\mathrm{kg} \cdot\right.$ ind. $^{-1}$ ) & 皮 Barks $\left(\mathrm{kg} \cdot\right.$ ind. $\left.^{-1}\right)$ \\
\hline $\begin{array}{l}\text { 1. 云、冷杉 Picea asperata } \\
\text { and Abies fabri }\end{array}$ & $\exp (-3.9744)\left(D^{2} H\right)^{0.9434}$ & $\exp (-4.6350)\left(D^{2} H\right)^{0.9257}$ & $\exp (-5.9391)\left(D^{2} H\right)^{0.9257}$ & $\exp (-5.2791)\left(D^{2} H\right)^{0.9457}$ & $\exp (-5.5587)\left(D^{2} H\right)^{0.8930}$ \\
\hline $\begin{array}{l}\text { 2. 油松 } \\
\text { Pinus tabulaeformis }\end{array}$ & $\exp (-3.8828)\left(D^{2} H\right)^{0.9359}$ & $\exp (-6.3807)\left(D^{2} H\right)^{1.1242}$ & $\exp (-5.3277)\left(D^{2} H\right)^{0.8812}$ & $\exp (-4.7557)\left(D^{2} H\right)^{0.9204}$ & $\exp (-5.1129)\left(D^{2} H\right)^{0.8649}$ \\
\hline $\begin{array}{l}\text { 3. 锐齿栋 Quercus aliena } \\
\text { var. acuteserrata }\end{array}$ & $\exp (-4.0347)\left(D^{2} H\right)^{0.9953}$ & $\exp (-8.4741)\left(D^{2} H\right)^{1.3674}$ & $\exp (-8.4170)\left(D^{2} H\right)^{1.0888}$ & $\exp (-3.3630)\left(D^{2} H\right)^{0.7773}$ & $\exp (-4.5914)\left(D^{2} H\right)^{0.8657}$ \\
\hline $\begin{array}{l}\text { 4. 柏木 } \\
\text { Cupressus funebris }\end{array}$ & $0.0427\left(D^{2} H\right)^{0.8545}$ & $0.0128\left(D^{2} H\right)^{0.8916}$ & $0.0258\left(D^{2} H\right)^{0.7037}$ & $0.0079\left(D^{2} H\right)^{0.9385}$ & - \\
\hline $\begin{array}{l}\text { 5. 杨、桦 Populus spp. and } \\
\text { Betula spp. }\end{array}$ & $\exp (-3.8023)\left(D^{2} H\right)^{0.9631}$ & $\exp (-5.9070)\left(D^{2} H\right)^{1.0903}$ & $\exp (-3.9108)\left(D^{2} H\right)^{0.6104}$ & $\exp (-3.2756)\left(D^{2} H\right)^{0.7692}$ & $\exp (-5.8330)\left(D^{2} H\right)^{0.9682}$ \\
\hline 6. 落叶松 Larix gmelinii & $\exp (-3.6844)\left(D^{2} H\right)^{0.9303}$ & $\exp (-7.6840)\left(D^{2} H\right)^{1.2554}$ & $\exp (-12.0638)\left(D^{2} H\right)^{1.4968}$ & $\exp (-5.1872)\left(D^{2} H\right)^{0.9709}$ & $\exp (-5.0754)\left(D^{2} H\right)^{0.8708}$ \\
\hline $\begin{array}{l}\text { 7. 华山松 } \\
\text { Pinus armandii }\end{array}$ & $\exp (-3.9041)\left(D^{2} H\right)^{0.9630}$ & $\exp (-4.0957)\left(D^{2} H\right)^{0.9186}$ & $\exp (-4.8359)\left(D^{2} H\right)^{0.7936}$ & $\exp (-8.3710)\left(D^{2} H\right)^{1.3456}$ & $\exp (-4.6176)\left(D^{2} H\right)^{0.8060}$ \\
\hline $\begin{array}{l}\text { 8. 栓皮柇 } \\
\text { Quercus variabilis }\end{array}$ & $\exp (-3.7447)\left(D^{2} H\right)^{0.9679}$ & $\exp (-4.8449)\left(D^{2} H\right)^{1.0013}$ & $\exp (-3.3569)\left(D^{2} H\right)^{0.6050}$ & $\exp (-2.9066)\left(D^{2} H\right)^{0.8144}$ & $\exp (-3.2565)\left(D^{2} H\right)^{0.7156}$ \\
\hline $\begin{array}{l}\text { 9. 辽东栋 } \\
\text { Quercus wutaishanica }\end{array}$ & $\left.0.0493\left(D^{2} H\right)\right)^{0.8514}$ & $0.0026\left(D^{2} H\right)^{1.1887}$ & $0.0119\left(D^{2} H\right)^{0.835}$ & $0.1009\left(D^{2} H\right)^{0.6879}$ & - \\
\hline $\begin{array}{l}\text { 10. 刺槐 } \\
\text { Robinia pseudoacacia }\end{array}$ & $0.0302\left(D^{2} H\right)^{0.9474}$ & $0.004\left(D^{2} H\right)^{1.0868}$ & $0.006\left(D^{2} H\right)^{0.8403}$ & $0.0119\left(D^{2} H\right)^{0.9501}$ & - \\
\hline $\begin{array}{l}\text { 11. 其他硬阔类 Other hard } \\
\text { broad-leaved species }\end{array}$ & $\exp (-3.8852)\left(D^{2} H\right)^{0.9803}$ & $\exp (-5.6360)\left(D^{2} H\right)^{1.0851}$ & $\exp (-4.5320)\left(D^{2} H\right)^{0.7377}$ & $\exp (-3.1575)\left(D^{2} H\right)^{0.7758}$ & $\exp (-4.4480)\left(D^{2} H\right)^{0.7713}$ \\
\hline $\begin{array}{l}\text { 12. 其他软阔类 Other soft } \\
\text { broad-leaved species }\end{array}$ & $0.021\left(D^{2} H\right)^{0.9642}$ & $0.0011\left(D^{2} H\right)^{1.1909}$ & $0.0022\left(D^{2} H\right)^{0.8595}$ & $0.053\left(D^{2} H\right)^{0.7452}$ & - \\
\hline
\end{tabular}

$D$ 为单株乔木胸径 $(\mathrm{cm}) ; H$ 为单株乔木高度 $(\mathrm{m})$ 。

$D$ and $H$ refer to tree diameter at breast height $(\mathrm{cm})$ and tree height $(\mathrm{m})$, respectively.

该层土壤> $2 \mathrm{~mm}$ 砾石所占百分比 $(\%)$ 。

\subsection{5 全省尺度森林碳储量估算}

对某一样地, 将调查求得各组分(乔木层、灌木 层、草本层、枯落物层和土壤层)的碳密度求和得到 该样地的森林生态系统碳密度 $\left(\mathrm{MgC} \cdot \mathrm{hm}^{-2}\right)$ 。甘肃全 省森林碳储量现状基于《第八次全国森林资源清查 甘肃省森林资源清查成果》进行估算, 该清查资料 代表2011年的森林资源状况。由于 20 世纪60年代以 来的乱砍滥伐, 甘肃全省约有 $3.0 \times 10^{7} \mathrm{hm}^{2}$ 的森林 受到严重破坏，导致调查过程中部分森林类型过熟 林样地重复较少, 因此本研究以同一林型各龄组的 加权平均碳密度代替该林型平均碳密度进行比较。 以某一森林类型为例, 根据样地调查先求得该林型 同一龄组森林生态系统各组分的平均碳密度, 之后 按不同龄组面积加权分别计算全省水平该森林生态 系统各组分的碳密度。全省天然林和人工林平均碳 密度分别按照不同植被类型面积加权平均求得。全 省尺度上的碳储量由不同林型各组分的碳密度乘以 相对应的面积加和求得。

\subsection{6 固碳速率的估算}

本研究固碳速率的估算仅涉及植被碳储量的固 碳速率。在样地调查和碳储量现状估算的基础上, 结合4次森林资源清查资料(1996、2001、2006和2011
年状况), 通过 4 个时期的全省植被碳储量变化估算 其固碳速率 $\left(\Delta C_{\mathrm{s}}, \operatorname{Tg~C} \cdot \mathrm{a}^{-1}\right)$, 公式如下:

$$
\Delta C_{s}=\frac{\left(C_{s 2}-C_{s 1}\right)}{\left(t_{2}-t_{1}\right)}
$$

式中, $C_{\mathrm{s} 1} 、 C_{\mathrm{s} 2}$ 分别代表 $t_{1} 、 t_{2}$ 时间的碳储量 $(\mathrm{Tg} C)$ 。

\section{2 结果和分析}

\section{1 甘肃省天然林、人工林生态系统碳密度及垂直 结构}

甘肃省天然林森林生态系统土壤平均有机碳密 度最高, 为 $207.28 \mathrm{MgC} \cdot \mathrm{hm}^{-2}$, 植被层各层平均碳密 度大小顺序为乔木层 $\left(86.75 \mathrm{Mg} \mathrm{C} \cdot \mathrm{hm}^{-2}\right)>$ 枯落物层 $\left(2.25 \mathrm{Mg} \mathrm{C} \cdot \mathrm{hm}^{-2}\right)>$ 灌木层 $\left(1.02 \mathrm{Mg} \mathrm{C} \cdot \mathrm{hm}^{-2}\right)>$ 草本层 $\left(0.50 \mathrm{Mg} \mathrm{C} \cdot \mathrm{hm}^{-2}\right)($ 表 4$)$ 。不同天然林类型中, 乔木 层、灌木层、草本层和枯落物层碳密度分别介于 $36.03-179.92 、 0.34-1.38 、 0.36-0.85$ 和 $1.47-8.35 \mathrm{Mg}$ $\mathrm{C} \cdot \mathrm{hm}^{-2}$ 之间，变异系数分别为 $75.52 \% 、 121.92 \%$ 、 $121.40 \%$ 和 $96.80 \%$ 。其中, 乔木层中碳密度较大的林 型为冷杉、云杉、铁杉寒温性针叶林, 最小林型为 杨树林, 灌木层碳密度最大和最小林型分别为冷杉 林和其他软阔类, 草本层碳密度最大和最小林型分 别为云杉林和冷杉林, 枯落物层碳密度最大和最小 的林型分别为其他松类和冷杉林。对土壤有机碳密 
表4 甘肃省天然林森林生态系统不同组分碳密度

Table 4 Carbon density in different components of natural forest ecosystems in Gansu Province

\begin{tabular}{lccccc}
\hline 森林类型 & \multicolumn{5}{c}{ 碳密度 Carbon density $\left(\mathrm{Mg} \mathrm{C}^{-\mathrm{hm}^{-2}}\right)$} \\
\cline { 2 - 6 } & $\begin{array}{c}\text { 乔木层 } \\
\text { Tree layer }\end{array}$ & $\begin{array}{c}\text { 灌木层 } \\
\text { Shrub layer }\end{array}$ & $\begin{array}{c}\text { 草本层 } \\
\text { Herb layer }\end{array}$ & $\begin{array}{c}\text { 枯落物层 } \\
\text { Litter layer }\end{array}$ & $\begin{array}{c}\text { 土壤层 } \\
\text { Soil layer }\end{array}$ \\
\hline 冷杉 Abies fabri & 179.92 & 1.38 & 0.36 & 1.47 & 383.18 \\
云杉 Picea asperata & 107.06 & 1.26 & 0.85 & 1.96 & 369.90 \\
铁杉 Tsuga chinensis & 125.71 & 0.99 & 0.44 & 2.93 & 391.91 \\
落叶松 Larix gmelinii & 102.61 & 0.87 & 0.71 & 2.75 & 296.44 \\
油松 Pinus tabulaeformis & 75.93 & 0.42 & 0.51 & 6.92 & 179.99 \\
华山松 Pinus armandii & 71.33 & 0.39 & 0.78 & 2.17 & 215.78 \\
其他松类 Other pines & 83.23 & 0.49 & 0.57 & 8.35 & 216.50 \\
柏木 Cupressus funebris & 64.15 & 0.57 & 0.54 & 1.54 & 362.56 \\
栋类 Quercus spp. & 88.85 & 1.34 & 0.41 & 1.79 & 152.00 \\
华木 Betula spp. & 63.85 & 0.75 & 0.40 & 2.75 & 160.11 \\
杨树 Populus spp. & 36.03 & 0.49 & 0.73 & 2.39 & 118.20 \\
其他硬阔类 Other hardwood broad-leaved species & 84.31 & 1.20 & 0.40 & 1.98 & 144.56 \\
其他软阔类 Other softwood broad-leaved species & 44.42 & 0.34 & 0.52 & 2.64 & 125.38 \\
针叶混交林 Mixed coniferous forest & 106.54 & 0.83 & 0.60 & 3.79 & 293.39 \\
阔叶混交林 Mixed broad-leaved forest & 71.09 & 1.01 & 0.47 & 2.34 & 155.40 \\
针榈混交林 Mixed coniferous and broad-leaved forest & 58.23 & 0.54 & 0.40 & 3.80 & 159.94 \\
加权平均 Weighted average & 86.75 & 1.02 & 0.50 & 2.25 & 207.28 \\
\hline
\end{tabular}

表5甘肃省人工林森林生态系统不同组分碳密度

Table 5 Carbon density in different components of plantations in Gansu Province

\begin{tabular}{lccccc}
\hline 森林类型 & \multicolumn{4}{c}{ 碳密度 Carbon density $\left(\mathrm{Mg} \mathrm{C}^{-2} \mathrm{hm}^{-2}\right)$} \\
\cline { 2 - 6 } & $\begin{array}{c}\text { 乔木层 } \\
\text { Tree layer }\end{array}$ & $\begin{array}{c}\text { 灌木层 } \\
\text { Shrub layer }\end{array}$ & $\begin{array}{c}\text { 草本层 } \\
\text { Herb layer }\end{array}$ & $\begin{array}{c}\text { 枯落物层 } \\
\text { Litter layer }\end{array}$ & $\begin{array}{c}\text { 土壤层 } \\
\text { Soil layer }\end{array}$ \\
\hline 冷杉 Abies fabri & 25.79 & 0.77 & 0.53 & 1.39 & 272.30 \\
云杉 Picea asperata & 28.52 & 1.26 & 0.53 & 0.78 & 338.34 \\
落叶松 Larix gmelinii & 33.13 & 0.69 & 0.52 & 1.54 & 218.36 \\
油松 Pinus tabulaeformis & 44.93 & 0.45 & 0.29 & 2.69 & 141.24 \\
华山松 Pinus armandii & 57.79 & 1.17 & 0.48 & 2.53 & 174.25 \\
其他松类 Other pines & 36.82 & 0.79 & 0.41 & 2.14 & 179.19 \\
柏木 Cupressus funebris & 22.38 & 0.77 & 0.62 & 0.90 & 232.82 \\
栋类 Quercus spp. & 48.35 & 0.01 & 0.43 & 2.23 & 53.90 \\
桦木 Betula spp. & 30.08 & 0.01 & 1.08 & 0.88 & 69.63 \\
杨树 Populus spp. & 59.44 & 0.01 & 0.55 & 0.81 & 90.25 \\
刺槐 Robinia pseudoacacia & 15.48 & 0.02 & 1.14 & 1.36 & 52.39 \\
其他硬阔类 Other hardwood broad-leaved species & 27.59 & 0.01 & 0.85 & 1.19 & 72.02 \\
其他软阔类 Other softwood broad-leaved species & 45.76 & 0.01 & 0.58 & 2.60 & 100.66 \\
针叶混交林 Mixed coniferous forest & 36.37 & 0.16 & 0.68 & 0.72 & 51.12 \\
阔叶混交林 Mixed broad-leaved forest & 27.18 & 0.01 & 0.72 & 1.07 & 34.28 \\
针阔混交林 Mixed coniferous and broad-leaved forest & 70.10 & 1.14 & 0.15 & 2.39 \\
加权平均 Weighted average & 31.39 & 0.22 & 0.81 & 1.37 & 328.21 \\
\hline
\end{tabular}

度频度分析显示, 甘肃省天然林土壤有机碳密度变 化范围在118.20-391.91 Mg C.hm² 之间, 变异系数为 $60.17 \%$, 呈右偏态分布, 但经对数转化后, 符合K-S
正态性检验 $(p>0.05)$ 。各天然林类型中, 土壤有机碳 密度较大的林型为铁杉、冷杉、云杉、柏木寒温性针 叶林，杨树林最小。各天然林林型中，土壤有机碳密

www.plant-ecology.com 
度是植被碳密度的1.64-5.43倍, 平均为2.63倍。

甘肃省人工林森林生态系统以土壤平均有机碳 密度最大, 为 $107.07 \mathrm{Mg} \mathrm{C} \cdot \mathrm{hm}^{-2}$, 植被层各层平均碳 密度大小顺序为乔木层 $\left(31.39 \mathrm{Mg} \mathrm{C} \cdot \mathrm{hm}^{-2}\right)>$ 枯落物 层 $\left(1.37 \mathrm{Mg} \mathrm{C} \cdot \mathrm{hm}^{-2}\right)>$ 草本层 $\left(0.81 \mathrm{Mg} \mathrm{C} \cdot \mathrm{hm}^{-2}\right)>$ 灌木 层 $\left(0.22 \mathrm{Mg} \mathrm{C} \cdot \mathrm{hm}^{-2}\right)$ (表5)。不同人工林类型中, 乔木 层、灌木层、草本层和枯落物层碳密度分别介于 15.48-70.10、0.01-1.26、0.15-1.14和 $0.72-2.69 \mathrm{Mg}$ $\mathrm{C} \cdot \mathrm{hm}^{-2}$, 变异系数分别为 $86.34 \% 、 170.95 \% 、 80.24 \%$ 和 $118.56 \%$ 。土壤有机碳密度变化范围在 $34.28-$ $338.34 \mathrm{Mg} \mathrm{C} \cdot \mathrm{hm}^{-2}$ 之间, 变异系数为 $75.91 \%$, 呈右 偏态分布, 但经对数转化后, 符合 K-S正态性检验 $(p>0.05)$ 。各人工林类型中, 土壤有机碳密度最大 和最小的林型分别为云杉林和阔叶混交林, 土壤 有机碳密度是植被碳密度的1.06-10.88, 平均为 4.08倍。对同一优势种, 天然林土壤有机碳密度均 高于人工林, 平均高出 $107.79 \%$, 除杨树林和其他 软阔类外, 天然林乔木层碳密度均高于人工林, 平 均高出 $178.02 \%$, 说明天然林的固碳能力显著高于 人工林。

从龄组划分来看, 甘肃省天然林、人工林植被 碳密度均表现为过熟林 $>$ 成熟林 $>$ 近熟林 $>$ 中龄林 $>$ 幼龄林, 且同一龄组天然林植被碳密度均高于人工 林(图1A)。天然林幼龄林、中龄林、近熟林、成熟 林和过熟林的植被碳密度分别为：58.89、71.46、 89.73、118.70和 $176.61 \mathrm{Mg} \mathrm{C} \cdot \mathrm{hm}^{-2}$, 比人工林分别高 了 $147.42 \% 、 84.99 \% 、 100.85 \% 、 67.51 \%$ 和 $102.55 \%$ 。 随着林龄的增加, 天然林的植被固碳能力增幅逐渐 增加, 而人工林的固碳增幅从幼龄林到中龄林最 大。甘肃省天然林土壤有机碳密度随着林龄的增加 逐渐增加, 但近熟林略小于中龄林, 人工林土壤有 机碳密度在近熟林中达到最大 $\left(186.79 \mathrm{Mg} \mathrm{C} \cdot \mathrm{hm}^{-2}\right)$, 在过熟林中最小 $\left(84.05 \mathrm{Mg} \mathrm{C} \cdot \mathrm{hm}^{-2}\right)$ (图1B)。

\section{2 甘肃省森林生态系统碳储量现状}

甘肃全省森林生态系统总碳储量为 $612.43 \mathrm{Tg}$ $\mathrm{C}$, 植被和土壤碳储量分别为 179.04 和 $433.39 \mathrm{Tg} \mathrm{C}$, 占全省总碳储量的 $29.23 \%$ 和 $70.77 \%$ (表6)。天然林 总碳储量为 $501.42 \mathrm{Tg} \mathrm{C}$, 是人工林的 4.52 倍。在天 然林各森林类型中, 冷杉、云杉林较高的植被和土 壤碳密度导致了其较大的碳储量, 占天然林生态系 统碳储量的 $17.78 \%$ 和 $18.51 \%$ 。栎类和阔叶混交林面 积较大, 合计占天然林面积的 $38.73 \%$, 因此, 对
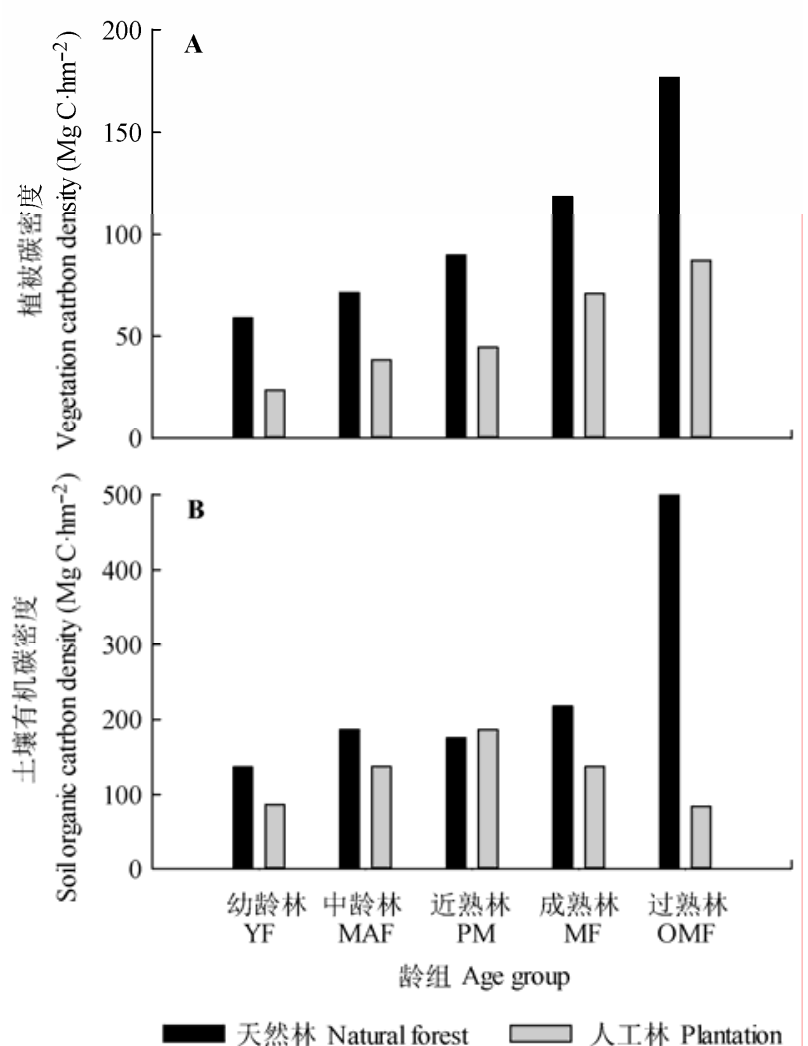

图1 甘肃省天然林、人工林不同龄组植被碳密度 $(\mathbf{A})$ 和土壤 有机碳密度 $(\mathbf{B})$ 。

Fig. 1 Vegetation carbon density (A) and soil organic carbon density (B) of different age groups in natural forests and plantations in Gansu Province. YF, MAF, PMF, MF and OMF refer to young forest, middle-aged forest, pre-mature forest, mature forest and over-mature forest, respectively.

天然林生态系统碳储量的贡献也大，分别达 $16.12 \%$ 和 $14.77 \%$ 。在人工林各森林类型中，面积分布大的 森林类型其碳储量也大, 刺槐、杨树和云杉人工林 面积合计占 $62.61 \%$, 对人工林碳储量的贡献率分别 达 $20.22 \%$ 、17.15\%和 $16.14 \%$ 。

\section{3 甘肃省植被碳储量固碳速率}

国家林业局自1994年森林资源清查时，森林郁 闭度标准从 0.3 改为 0.2 , 为采用统一标准比较不同 时期森林固碳的动态变化, 本研究使用1996年、 2001年、2006年和2011年连续4次甘肃省森林资源清 查资料。此外, 由于土壤碳储量受植被类型及土壤 类型等多因素的共同影响, 本研究仅比较植被层碳 储量年变化及固碳速率。甘肃省天然林碳储量随时 间变化呈上升趋势，在1996年、2001年、2006年和 2011年分别达到132.47、135.27、143.44和152.41 Tg C, 且中龄林和成熟林碳储量在各个时期比重最大, 
表6 甘肃省森林生态系统碳储量

Table 6 Forest ecosystem carbon stocks in Gansu Province

\begin{tabular}{|c|c|c|c|c|c|c|}
\hline \multirow[t]{2}{*}{$\begin{array}{l}\text { 森林类型 } \\
\text { Forest type }\end{array}$} & \multicolumn{3}{|c|}{$\begin{array}{c}\text { 天然林碳储量 } \\
\text { Natural forest carbon stock (Tg C) }\end{array}$} & \multicolumn{3}{|c|}{$\begin{array}{c}\text { 人工林碳储量 } \\
\text { Planted forest carbon stock }(\operatorname{Tg~C})\end{array}$} \\
\hline & $\begin{array}{c}\text { 面积 } \\
\text { Area }\left(100 \mathrm{hm}^{2}\right) \\
\end{array}$ & $\begin{array}{c}\text { 植被层 } \\
\text { Vegetation layer }\end{array}$ & $\begin{array}{c}\text { 土壤层 } \\
\text { Soil layer }\end{array}$ & $\begin{array}{c}\text { 面积 } \\
\text { Area }\left(100 \mathrm{hm}^{2}\right) \\
\end{array}$ & $\begin{array}{c}\text { 植被层 } \\
\text { Vegetation layer }\end{array}$ & $\begin{array}{c}\text { 土壤层 } \\
\text { Soil layer }\end{array}$ \\
\hline 冷杉 Abies fabri & 1574 & 28.83 & 60.31 & 12 & 0.03 & 0.33 \\
\hline 云杉 Picea asperata & 1929 & 21.44 & 71.35 & 485 & 1.51 & 16.41 \\
\hline 铁杉 Tsuga chinensis & 12 & 0.16 & 0.47 & - & - & - \\
\hline 落叶松 Larix gmelinii & 27 & 0.29 & 0.80 & 577 & 2.07 & 12.60 \\
\hline 油松 Pinus tabulaeformis & 292 & 2.45 & 5.26 & 475 & 2.30 & 6.71 \\
\hline 华山松 Pinus armandii & 544 & 4.06 & 11.74 & 156 & 0.97 & 2.72 \\
\hline 其他松类 Other pines & 9 & 0.08 & 0.19 & 9 & 0.04 & 0.16 \\
\hline 柏木 Cupressus funebris & 506 & 3.38 & 18.35 & 18 & 0.04 & 0.42 \\
\hline 栋类 Quercus spp. & 3307 & 30.55 & 50.27 & 9 & 0.05 & 0.05 \\
\hline 桦木 Betula spp. & 1813 & 12.28 & 29.03 & 6 & 0.02 & 0.04 \\
\hline 杨树 Populus spp. & 551 & 2.18 & 6.51 & 1260 & 7.66 & 11.37 \\
\hline 刺槐 Robinia pseudoacacia & - & - & - & 3189 & 5.74 & 16.71 \\
\hline 其他硬阔类 Other hardwood broad-leaved species & 1650 & 14.50 & 23.85 & 1091 & 3.23 & 7.86 \\
\hline 其他软阔类 Other softwood broad-leaved species & 631 & 3.02 & 7.91 & 164 & 0.80 & 1.65 \\
\hline 针叶混交林 Mixed coniferous forest & 42 & 0.47 & 1.23 & 39 & 0.15 & 0.20 \\
\hline 阔叶混交林 Mixed broad-leaved forest & 3215 & 24.08 & 49.96 & 193 & 0.56 & 0.66 \\
\hline 针阔混交林 Mixed coniferous and broad-leaved forest & 736 & 4.63 & 11.77 & 198 & 1.46 & 6.50 \\
\hline 合计 Total & 16838 & 152.41 & 349.01 & 7881 & 26.63 & 84.38 \\
\hline
\end{tabular}

占 $50.10 \%-53.88 \%$ (图 $2 \mathrm{~A}$ )。人工林碳储量随时间的 增加增幅较大，从1996年到2011年增加了 $107.93 \%$ 。 人工林各龄组中, 幼、中龄林碳储量比重较大, 各个 时期合计占人工林碳储量的 63.70\%-83.21\%（图 2B)。各个时期不同龄组中, 天然林植被碳储量以中 龄林最高, 人工林以幼龄林最高。各个时期同一龄 组天然林碳储量占全省植被碳储量的比例均高于人 工林，是人工林的5.53-10.34倍。天然林分别占同期 全省碳储量的 $91.18 \% 、 90.33 \% 、 84.68 \%$ 和 $85.13 \%$, 说明天然林是甘肃省森林植被碳汇功能的主要贡献 者，同时人工林的碳汇功能正处于上升阶段。

甘肃省天然林从1996年到2011年平均每年固碳 $1.33 \mathrm{Tg} \mathrm{C}$, 比人工林高 $0.41 \mathrm{Tg} \mathrm{C}$ 。天然林在19962001年和2006-2011年两个5年期间平均固碳量均高 于人工林, 分别高出 0.23 和 $1.65 \mathrm{Tg} \mathrm{C}$ 。而在 2001-2006年期间，人工林的平均固碳量高于天然 林，这主要归因于1998年以来相继开展的“天然林 资源保护工程”和“退耕还林”等一系列林业工程， 甘肃省加大了人工林种植面积, 幼、中龄林面积在 5 年期间共增加了 $86.04 \%$, 使得人工林碳储量也相应 增加了 $86.94 \%$ 。

\section{3 讨论}

3.1 甘肃省森林生态系统碳密度、碳储量现状

本研究通过样地调查结合森林资源清查资料, 得出甘肃省森林生态系统总碳储量为 $612.43 \mathrm{Tg} \mathrm{C}$, 占我国森林生态系统的 $2.18 \%-3.74 \%$ (周玉荣等, 2000; 李克让等, 2003)。其中土壤碳为 $433.39 \mathrm{Tg} \mathrm{C}$, 是植被碳储量的 2.42 倍，约 $71 \%$ 的碳储存于土壤中, 说明该区土壤碳库作为森林生态系统内最大的碳 库, 将对未来气候变化发挥重要作用。甘肃省乔木 层碳储量为 $170.80 \mathrm{Tg} \mathrm{C}$, 比赵敏和周广胜(2004) (76.69 Tg C, 1989-1993年)、王效科等(2001) (71.92 $\mathrm{Tg} \mathrm{C}, 1984-1988$ 年)、吴庆标等(2008) (78.77 Tg C, 1996-2000年)的估算分别提高了 $122.71 \% 、 137.49 \%$ 、 $116.83 \%$ ，表明甘肃省森林植被在近十几年来发挥 着可观的碳汇作用。

甘肃省森林乔木层平均碳密度为 $69.10 \mathrm{Mg}$ $\mathrm{C} \cdot \mathrm{hm}^{-2}$, 高于方精云等(2007)(41.0 Mg C$\cdot \mathrm{hm}^{-2}$ )和 Zhang等(2013a)(40.12 Mg C.hm ${ }^{-2}$ )分别估算的全国 森林生态系统乔木层平均碳密度，同时也高于同期 毗邻省区陕西(31.38 Mg C·hm ${ }^{-2}$ )(崔高阳等, 2015)和 


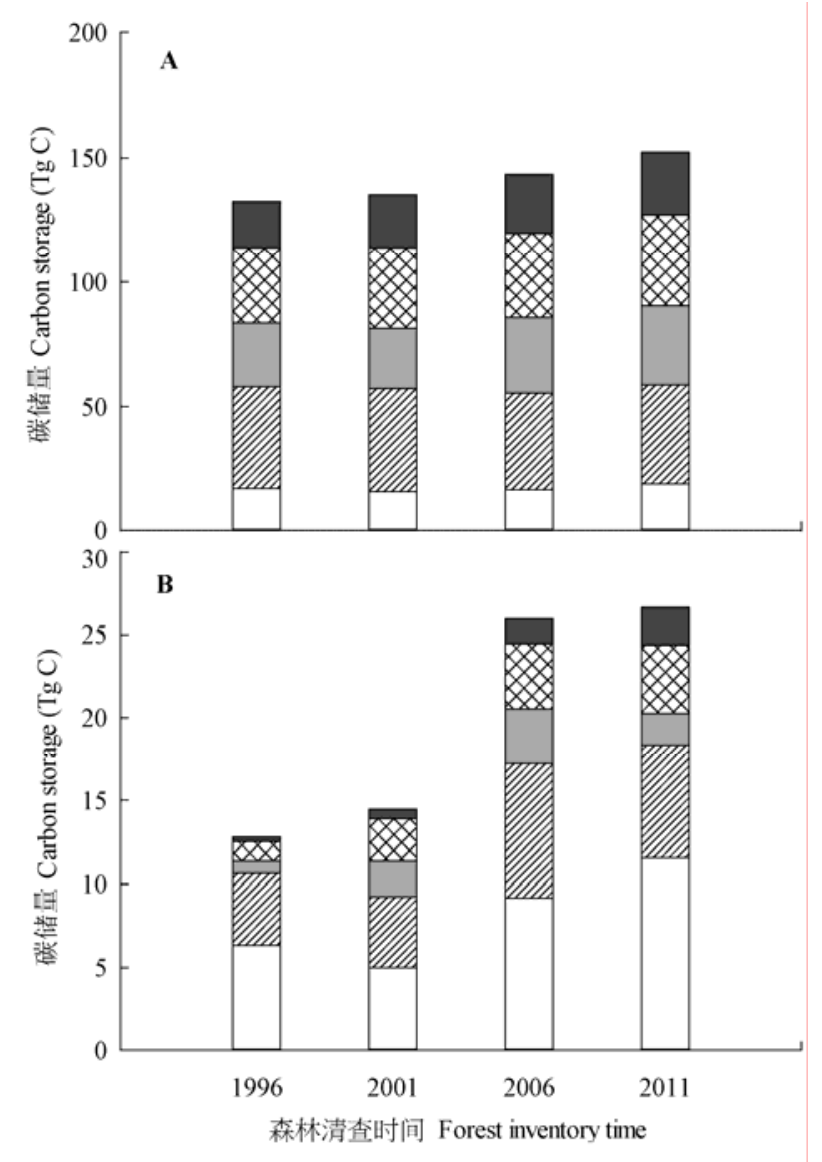

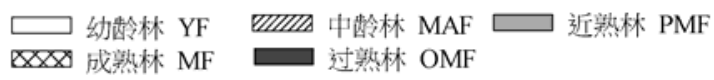

图2 甘肃省天然林 $(\mathbf{A})$ 、人工林 $(\mathbf{B})$ 不同龄组植被层碳储量 随时间的变化。

Fig. 2 Changes in vegetation carbon stocks for different age groups in natural forests (A) and plantations (B) with time of the national forest inventory in Gansu Province. YF, MAF, PMF, MF and OMF refer to young forest, middle-aged forest, pre-mature forest, mature forest and over-mature forest, respectively.

宁夏(18.53 $\left.\mathrm{Mg} \mathrm{C} \cdot \mathrm{hm}^{-2}\right)$ (高阳等, 2014)。究其原因, 一方面是由于该区分布有大量云冷杉等寒温性针叶 林, 为本区演替的顶级群落, 其面积和蓄积合计占 全省森林的 $20.75 \%$ 和 $39.19 \%$, 森林碳储量在单位面 积的积累较高。另一方面是方法性的差异, 目前对 区域尺度的研究大多采用生物量转换因子连续函数 法推算乔木层生物量, 乘以 0.45 或 0.5 作为碳密度, 而忽略了树种及器官间的差异, 使得结果具有一定 差异(方精云等, 2007; Zhang et al., 2013a)。甘肃省天 然林乔木层平均碳密度为 $86.75 \mathrm{Mg} \mathrm{C} \cdot \mathrm{hm}^{-2}$, 而人工 林仅为 $31.39 \mathrm{MgC} \cdot \mathrm{hm}^{-2}$, 这是由于甘肃省人工林中 有 $83.85 \%$ 的乔木林面积处于幼、中龄林阶段, 具有

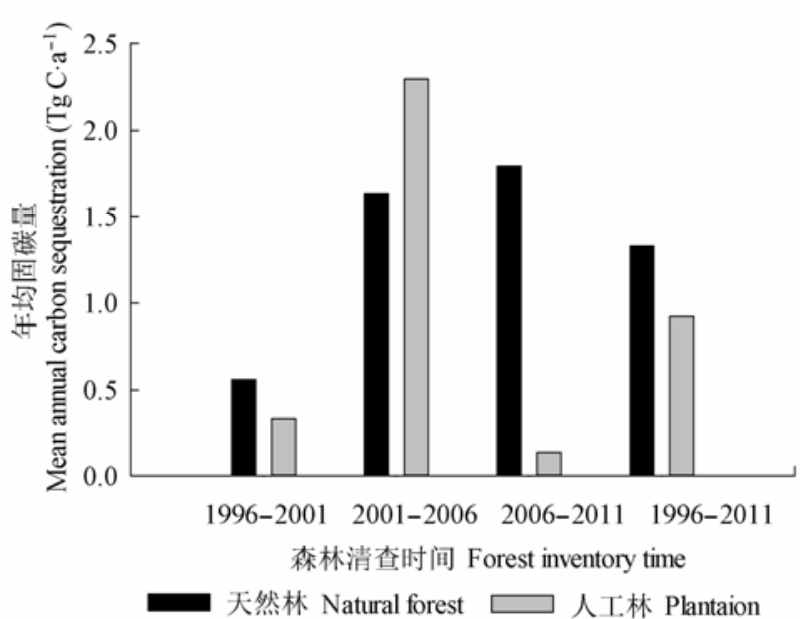

图3 甘肃省天然林、人工林植被层年均固碳量。

Fig. 3 Mean annual carbon sequestration in natural forests and plantations in Gansu Province.

较低的生物量碳。全国森林生物量碳有 $85.30 \%$ 贮存 在中龄林和成熟林中，随着林龄的增加，幼、中龄林 在该区将发挥更大的碳汇潜力。甘肃省人工林平均 土壤有机碳密度 $\left(107.07 \mathrm{Mg} \mathrm{C} \cdot \mathrm{hm}^{-2}\right)$ 接近于我国人 工林平均水平 $\left(107.10 \mathrm{Mg} \mathrm{C} \cdot \mathrm{hm}^{-2}\right)$ (刘世荣等, 2011)。 天然林平均土壤碳密度为 $207.28 \mathrm{Mg} \mathrm{C} \cdot \mathrm{hm}^{-2}$, 远高 于我国天然林平均水平 $\left(109.10 \mathrm{Mg} \mathrm{C} \cdot \mathrm{hm}^{-2}\right.$ ) (刘世荣 等, 2011), 这是由于云冷杉、柏木等寒温性针叶林 具有较高的土壤有机碳密度, 利用其面积加权平均 后, 全省仍处在一个高土壤碳密度水平。本研究中 的云冷杉、柏木等寒温性针叶林的平均土壤有机碳 密度为 $373.75 \mathrm{Mg} \mathrm{C} \cdot \mathrm{hm}^{-2}$, 接近于周玉荣等(2000)对 全国云冷杉林土壤有机碳密度的估计值(360.79 Mg $\mathrm{C} \cdot \mathrm{hm}^{-2}$ )。本研究中云冷杉、柏木等寒温性针叶林分 布在海拔2 191-3 $404 \mathrm{~m}$, 且有部分森林为原始森 林，地表枯落物厚、温度低、土壤相对湿度大、冻 结时间长, 土壤异养呼吸受到限制, 而有利于土壤 有机质的积累(Tewksbury \& van Miegroet, 2007), 使 得该区土壤有机碳密度较高, 成为我国森林生态系 统重要的土壤碳库。

\section{2 甘肃省森林植被固碳量及碳汇潜力预测}

甘肃省天然林、人工林植被碳储量从1996年到 2011年分别增加了 $19.95 、 13.82 \mathrm{Tg} \mathrm{C}$, 年平均固碳量 为 $1.33 、 0.92 \mathrm{Tg} \mathrm{C} \cdot \mathrm{a}^{-1}$, 高于同期山西省天然林 $(0.86$ $\left.\mathrm{Tg} \mathrm{C} \cdot \mathrm{a}^{-1}\right)$ 和人工林 $\left(0.37 \mathrm{Tg} \mathrm{C} \cdot \mathrm{a}^{-1}\right)$ 年平均固碳量(王 宁, 2014), 也高于同期青藏高原高寒区阔叶林年平 
均固碳量 $\left(0.64 \mathrm{Tg} \mathrm{C} \cdot \mathrm{a}^{-1}\right)$ (王建等, 2016)。对不同时期 来说, 甘肃省植被年平均固碳量 $\left(2.25 \mathrm{Tg} \mathrm{C} \cdot \mathrm{a}^{-1}\right)$ 低于 四川省(含重庆)(6.05 $\mathrm{Tg} \mathrm{C} \cdot \mathrm{a}^{-1}, 1994-2003$ 年)(黄从德 等, 2008a)、广东省(3.25 Tg C $\cdot \mathrm{a}^{-1}, 1997-2007$ 年) (叶金 盛和余光辉, 2010), 远高于黑龙江省 $\left(-2.28 \mathrm{Tg} \mathrm{C} \cdot \mathrm{a}^{-1}\right.$, 1994-2003年) (焦燕和胡海清, 2005)、辽宁省(1.91 Tg $\mathrm{C} \cdot \mathrm{a}^{-1}, 1995-2000$ 年) (王雪军等, 2008)等其他省份。说 明甘肃省森林在全国森林中具有较强的碳汇功能, 在全国尤其是中西部森林碳库中占有重要地位。

造林和再造林是减缓 $\mathrm{CO}_{2}$ 排放的主要途径之一 (Steffen et al., 1998), 我国人工林自20世纪70年代 末期以来导致的碳汇增加了 $0.45 \mathrm{Pg} \mathrm{C}$, 对我国森林 总碳汇的贡献率超过 $80 \%$ (Fang et al., 2001)。有研究 表明, 在恰当的人为管理与经营下, 同一地区人工 林(203 Mg C $\cdot \mathrm{hm}^{-2}$ ) 比天然林 $\left(162 \mathrm{Mg} \mathrm{C} \cdot \mathrm{hm}^{-2}\right)$ 具有较 高的生物量碳密度(Baishya et al., 2009)。甘肃省 人工林面积达 $78.81 \times 10^{4} \mathrm{hm}^{2}$, 且幼中龄林面积占 $83.85 \%$, 各植被类型植被层碳密度较小 $(18.00-$ $73.78 \mathrm{Mg} \mathrm{C} \cdot \mathrm{hm}^{-2}$ ), 其碳储存密度尚未达到最大, 若 能减少人为破坏与干扰, 加强营林管理, 幼、中龄林 将是未来该区碳汇的最大潜力所在, 人工林在植被 碳储量中的比例会不断提高。

\section{3 固碳估算结果的不确定性}

森林碳汇的增加主要是来自森林再生长和增强 生长, 从而有更多的有机碳进入森林生态系统。然 而, 森林碳汇受自然和人为多种因素的影响, 如环 境污染(Schimel, 1995)、氮沉降(Vetter et al., 2005)、 森林采伐(Pennock \& van Kessel, 1997)、土地覆被/ 利用变化(Wiesmeier et al., 2015)、甚至昆虫灾害 (Kurz \& Apps, 1999)等都会引起森林植被及土壤有 机碳库的变化。因此, 准确地估算大尺度碳汇量具 有一定难度, 需要在同一标准下更精细化的研究。 对森林生态系统碳库的估算, 首先是量化乔木层、 林下灌草层、枯落物层及土壤层的碳库分配特征。 然而, 早期的研究仅是针对乔木层的碳汇研究, 由 于方法间的差异, 使得对碳储量的估算具有一定的 不确定性, 此外, 林下灌草层、枯落物、土壤等信息 缺乏使得对森林生态系统碳库的动态研究成为难 点。以国家第三次森林资源清查资料(1989-1993年) 为基础, 方精云和陈安平(2001)、王效科等(2001)、 赵敏和周广胜(2004)、吴庆标等(2008)采用不同方法 估算甘肃省植被碳储量的结果分别为 $92.78 、 71.92$ 、
76.69、74.25 Tg C，误差达 $8.86 \%-17.58 \%$ 。

甘肃全省植被和土壤有机碳密度均高于全国及 毗邻省区水平, 低于天山雪岭杉(Picea schrenkiana) 的植被( $92.57 \mathrm{Mg} \cdot \mathrm{C} \mathrm{hm}$ ) 和土壤有机碳密度(452.00 $\mathrm{Mg} \cdot \mathrm{C} \mathrm{hm}^{-2}$ ) (许文强等, 2016), 其中存在的不确定因 素较多。首先是来自土壤有机碳密度的误差, 土壤 有机碳的空间变异性较大, 其大小受土壤类型、地 形、气候、林龄及人为干扰等因素的共同影响。由 于甘肃省地形复杂, 海拔 $3000 \mathrm{~m}$ 以上的山原约占 全省土地总面积的 $20 \%$, 森林分布具有很大的异质 性, 本研究中约有 $37 \%$ 的样地分布在海拔 2000-3 $400 \mathrm{~m}$, 而海拔是导致针叶林土壤有机碳密 度变异的主导因子(解宪丽等, 2004)。甘肃全省212 个样地土壤有机碳密度范围为28.24-649.44 Mg $\mathrm{C} \cdot \mathrm{hm}^{-2}$, 变异系数为 $70.21 \%$, 所有剖面土壤有机碳 密度的频度分布呈右偏态分布, 但经过对数转化后 通过K-S正态性检验 $(p>0.05)$, 因而中位数(154.29 $\mathrm{Mg} \mathrm{C} \cdot \mathrm{hm}^{-2}$ )在统计学上更能代表该省的土壤有机碳 密度平均水平, 但考虑到甘肃省森林分布的异质性, 本文在计算过程中使用了面积加权来计算各组分的 碳密度, 也是土壤有机碳密度偏大的原因之一。其 次, 本文虽遵循了《生态系统固碳现状、速率和潜 力研究调查规范》的样点布设方法, 但在实际操作 中并非完全随机布点, 而是倾向于调查易于接近和 林分状况较好的林型, 可能造成区域森林碳储量的 估算相对较高。另一方面由于 20 世纪 60 年代以来的 乱砍滥伐, 甘肃省森林大面积 $\left(3.0 \times 10^{7} \mathrm{hm}^{2}\right)$ 受到严 重破坏, 因此在调查过程中天然林中仅云冷杉有过 熟林, 且样地较少, 共计 3 个。这 3 个样地的林龄分别 为: 170年、200年、220-270年左右的过熟林, 样地 内云冷杉平均胸径分别为 $32.35 、 22.01$ 和 $18.05 \mathrm{~cm}$, 平均树高为 $15.62 、 10.60$ 和 $14.03 \mathrm{~m}$, 样地内除有 60-90 cm的大径级乔木外, 林下更新情况较好, 存 在较多的幼树, 因而具有较高的生物量碳密度。加 之这3个样地海拔分别为: $3191 、 3404$ 和 $3268 \mathrm{~m}$, 均为原始森林, 地表枯落物相对较厚, 温度低, 土 壤有机质分解缓慢, 因而土壤有机碳密度也相应较 高。第三, 森林清查资料仅记录了胸径 $\geqslant 5 \mathrm{~cm}$ 以上 的乔木, 本研究乔木起测胸径为 $2 \mathrm{~cm}$, 且 $2-5 \mathrm{~cm}$ 胸 径的乔木碳储量占甘肃省全部乔木碳储量的 $1.04 \%$ 。也有研究表明, 20 年以下人工林中胸径小于 $10 \mathrm{~cm}$ 的乔木占整个样地生物量的 $15.1 \%$ (Preece et 
al., 2012), 若忽略胸径 $5 \mathrm{~cm}$ 以下的乔木贡献量, 将 增加区域尺度碳汇现状的估算误差。此外, 对森林 生态系统碳库估算的另一误差是来自土壤剖面深度 的差异, 由于部分研究区域土壤土层较薄, 若全部 以 $1 \mathrm{~m}$ 参考标准来估算区域尺度的土壤碳储量, 将 增加估算误差。因此, 方法标准化、时间同步化, 并 有效地结合不同时空尺度下的样地清查资料、野外 监测数据、遥感数据的空间特征以及模型模拟等, 将有效地降低森林固碳估算的不确定性, 以更准确 地反映区域及更大尺度的碳收支平衡。

基金项目 中国科学院战略性先导科技专项(XDA05050202)和中国博士后科学基金(2015M580877)。

致谢 感谢国家林业局西北林业调查规划设计院、 甘肃省林业厅和各市林业部门在野外采样过程中的 支持与配合。

\section{参考文献}

Baishya R, Barik SK, Upadhaya K (2009). Distribution pattern of aboveground biomass in natural and plantation forests of humid tropics in northeast India. Tropical Ecology, 50, 295-304.

Chen XG, Zhang XQ, Zhang YP, Wan CB (2009). Carbon sequestration potential of the stands under the Grain for Green Program in Yunnan Province, China. Forest Ecology and Management, 258, 199-206.

Cheng TR, Ma QY, Feng ZK, Luo X (2007a). Research on forest biomass in Xiaolong Mountains, Gansu Province. Journal of Beijing Forestry University, 29(1), 31-36. (in Chinese with English abstract) [程堂仁, 马钦彦, 冯仲科, 罗旭 (2007a). 甘肃小陇山森林生物量研究. 北京林业 大学学报, 29(1), 31-36.]

Cheng TR, Feng J, Ma QY, Feng ZK, Kang FF, Zhang YL (2007b). Forest biomass and carbon storage of Quercus aliena var. acuteserrata stand-types in Xiaolong Mountains, Gansu Province. Journal of Beijing Forestry University, 29(S2), 209-215. (in Chinese with English abstract) [程堂仁, 冯菁, 马钦彦, 冯仲科, 康峰峰, 张彦 林 (2007b). 甘肃小陇山锐齿栋林生物量及其碳库研究. 北京林业大学学报, 29(S2), 209-215.]

Cui GY, Chen YM, Cao Y, An CC (2015). Analysis on carbon stock distribution patterns of forest ecosystems in Shaanxi Province. Chinese Journal of Plant Ecology, 39, 333-342. (in Chinese with English abstract) [崔高阳, 陈云明, 曹 扬, 安淳淳 (2015). 陕西省森林生态系统碳储量分布格 局分析. 植物生态学报, 39, 333-342.]

Dixon RK, Solomon A, Brown S, Houghton R, Trexier M, Wisniewski J (1994). Carbon pools and flux of global forest ecosystem. Science, 265, 171-171.
Fang JY, Chen AP (2001). Dynamic forest biomass carbon pools in China and their significance. Acta Botanica Sinica, 43, 967-973. (in Chinese with English abstract) [方 精云, 陈安平 (2001). 中国森林植被碳库的动态变化及 其意义. 植物学报, 43, 967-973.]

Fang JY, Chen AP, Peng CH, Zhao SQ, Ci L (2001). Changes in forest biomass carbon storage in China between 1949 and 1998. Science, 292, 2320-2322.

Fang JY, Guo ZD, Piao SL, Chen AP (2007). Terrestrial vegetation carbon sinks in China, 1981-2000. Science in China Series D: Earth Sciences, 37, 804-812. (in Chinese) [方精 云, 郭兆迪, 朴世龙, 陈安平 (2007). 1981-2000年中国 陆地植被碳汇的估算. 中国科学 $\mathrm{D}$ 辑: 地球科学, 37, 804-812.]

Gao Y, Jin JW, Cheng JM, Su JS, Zhu RB, Ma ZR, Liu W (2014). Carbon sequestration status of forest ecosystems in Ningxia Hui Autonomous Region. Chinese Journal of Applied Ecology, 25, 639-646. (in Chinese with English abstract） [高阳，金晶炜，程积民，苏纪帅，朱仁斌，马正 锐, 刘伟 (2014). 宁夏回族自治区森林生态系统固碳现 状. 应用生态学报, 25, 639-646.]

Guan JH, Zhou HS, Deng L, Zhang JG, Du S (2015). Forest biomass carbon storage from multiple inventories over the past 30 years in Gansu Province, China: Implications from the age structure of major forest types. Journal of Forestry Research, 26, 887-896.

Houghton R (2005). Aboveground forest biomass and the global carbon balance. Global Change Biology, 11, 945-958.

Huang CD, Zhang J, Yang WQ, Tang X, Zhao AJ (2008a). Dynamics on forest carbon stock in Sichuan Province and Chongqing City. Acta Ecologica Sinica, 28, 966-975. (in Chinese with English abstract) [黄从德, 张健, 杨万勤, 唐宵, 赵安㺵 (2008a). 四川省及重庆地区森林植被碳 储量动态. 生态学报, 28, 966-975.]

Huang CD, Zhang J, Yang WQ, Zhang GQ (2008b). Characteristics of carbon stock in artificial forest ecosystem in Sichuan Province of China. Chinese Journal of Applied Ecology, 19, 1644-1650. (in Chinese with English abstract) [黄从德, 张健, 杨万勤, 张国庆 (2008b). 四川 人工林生态系统碳储量特征. 应用生态学报, 19, 16441650.]

Jiao Y, Hu HQ (2005). Carbon storage and its dynamics of forest vegetations in Heilongiang Province. Chinese Journal of Applied Ecology, 16, 2248-2252. (in Chinese with English abstract) [焦燕, 胡海清 (2005). 黑龙江森 林植被碳储量及其动态变化. 应用生态学报, 16, 22482252.]

Kurz WA, Apps MJ (1999). A 70-year retrospective analysis of carbon fluxes in the Canadian forest sector. Ecological Applications, 9, 526-547.

Li HK, Lei YC, Zeng WS (2011). Forest carbon storage in 
China estimated using forestry inventory data. Scientia Silvae Sinicae, 47(7), 7-12. (in Chinese with English abstract) [李海奎, 雷渊才, 曾伟生 (2011). 基于森林清查 资料的中国森林植被碳储量. 林业科学, 47(7), 7-12.]

Li KR, Wang SQ, Cao MK (2003). Vegetation and soil carbon storage in China. Science in China Series D: Earth Sciences, 33, 72-80. (in Chinese) [李克让, 王绍强, 曹明奎 (2003). 中国植被和土壤碳贮量. 中国科学 $\mathrm{D}$ 辑: 地球科 学, 33, 72-80.]

Liu SR, Wang H, Luan JW (2011). A review of research progress and future prospective of forest soil carbon stockand soil carbon process in China. Acta Ecologica Sinica, 31, 5437-5448. (in Chinese with English abstract) [刘世荣, 王晖, 奕军伟 (2011). 中国森林土壤碳储量与土壤碳过 程研究进展. 生态学报, 31, 5437-5448.]

Peng HH, Jiang HM, Zhao CY (2010). Carbon storage of forest vegetation and its spatial distribution in Gansu Province. Journal of Arid Land Resources and Environment, 24(7), 154-158. (in Chinese with English abstract) [彭焕华, 姜 红梅, 赵传燕 (2010). 甘肃省森林植被碳咜量及空间分 布特征分析. 干旱区资源与环境, 24(7), 154-158.]

Peng SL, Li YL, Ren H, Zhao P (2002). Progress in research on soil respiration under the global change. Advanced in Earth Sciences, 17, 705-713. (in Chinese with English abstract). [彭少麟, 李跃林, 任海, 赵平 (2002). 全球变化 条件下的土壤呼吸效应. 地球科学进展, 17, 705-713.]

Peng SZ, Zhao CY, Zheng XL, Xu ZL, He L (2011). Spatial distribution characteristics of the biomass and carbon storage of Qinghai spruce (Picea crassifolia) forest in Qilian Mountains. Chinese Journal of Applied Ecology, 22, 1689-1694. (in Chinese with English abstract) [彭守 璋, 赵传燕, 郑祥霖, 许仲林, 何否 (2011). 祁连山青 海云杉林生物量和碳储量空间分布特征. 应用生态学 报, 22, 1689-1694.]

Pennock DJ, van Kessel C (1997). Effect of agriculture and of clear-cut forest harvest on landscape-scale soil organic carbon storage in Saskatchewan. Canadian Journal of Soil Science, 77, 211-218.

Preece ND, Crowley GM, Lawes MJ, Van Oosterzee P (2012). Comparing above-ground biomass among forest types in the Wet Tropics: Small stems and plantation types matter in carbon accounting. Forest Ecology and Management, 264, 228-237.

Ren H, Chen H, Li L, Li P, Hou C, Wan H, Zhang Q, Zhang P (2013). Spatial and temporal patterns of carbon storage from 1992 to 2002 in forest ecosystems in Guangdong, Southern China. Plant and Soil, 363(1-2), 123-138.

Ren H, Chen H, Li ZA, Han WD (2010). Biomass accumulation and carbon storage of four different aged Sonneratia apetala plantations in Southern China. Plant and Soil, 327(1-2), 279-291.
Ren H, Li LJ, Liu Q, Wang X, Li YD, Hui DF, Jian SG, Wang J, Yang H, Lu HF, Zhou GY, Tang XL, Zhang QM, Wang D, Yuan LL, Chen XB (2014). Spatial and temporal patterns of carbon storage in forest ecosystems on Hainan Island, southern China. PLOS ONE, 9(9), e108163.

Schimel DS (1995). Terrestrial ecosystems and the carbon cycle. Global Change Biology, 1, 77-91.

Steffen W, Noble I, Canadell J, Apps M, Schulze E-D, Jarvis PG (1998). The terrestrial carbon cycle: Implications for the Kyoto Protocol. Science, 280, 1393-1394.

Technical Manual Writing Group of Ecosystem Carbon Sequestration Project (2015). Observation and Investigation for Carbon Sequestration in Terrestrial Ecosystems. Science Press, Beijing. (in Chinese) [生态系统固碳项目技术 规范编写组 (2015). 生态系统固碳观测与调查技术规 范. 科学出版社, 北京.]

Tewksbury CE, van Miegroet H (2007). Soil organic carbon dynamics along a climatic gradient in a southern Appalachian spruce-fir forest. Canadian Journal of Forest Research, 37, 1161-1172.

Vetter M, Wirth C, Bottcher H, Churkina G, Schulze ED, Wutzler T, Weber G (2005). Partitioning direct and indirect human-induced effects on carbon sequestration of managed coniferous forests using model simulations and forest inventories. Global Change Biology, 11, 810-827.

Wang J, Wang GX, Wang CT, Ran F, Chang RY (2016). Carbon storage and potentials of the broad-leaved forest in alpine region of the Qinghai-Xizang Plateau, China. Chinese Journal of Plant Ecology, 40, 374-384. [王建, 王根绪, 王长庭, 由飞, 常瑞英 (2016). 青藏高原高寒区阔叶林 植被固碳现状、速率和潜力. 植物生态学报, 40 , 374-384.]

Wang N (2014). Study on Distribution Patterns of Carbon Density and Carbon Stock in the Forest Ecosystem of Shanxi. Beijing Forestry University, Beijing. 122-126. (in Chinese) [王宁 (2014). 山西森林生态系统碳密度分配格局 及碳储量研究. 博士学位论文, 北京林业大学, 北京. 122-126.]

Wang XC, Qi G, Yu DP, Zhou L, Dai LM (2011). Carbon storage, density, and distribution in forest ecosystems in Jilin Province of Northeast China. Chinese Journal of Applied Ecology, 22, 2013-2020. (in Chinese with English abstract) [王新闯, 齐光, 于大炮, 周莉, 代力民 (2011). 吉林省森林生态系统的碳储量、碳密度及其分. 应用生 态学报, 22, 2013-2020.]

Wang XJ, Huang GS, Sun YJ, Fu X, Han AH (2008). Forest carbon storage and dynamics in Liaoning Province from 1984 to 2000. Acta Ecologica Sinica, 28, 4757-4764. (in Chinese with English abstract) [王雪军, 黄国胜, 孙玉军, 付晓, 韩爱惠 (2008). 近20年辽宁省森林碳储量及其动 态变化. 生态学报, 28, 4757-4764.]

www.plant-ecology.com 
Wang XK, Feng ZW, Ouyang ZY (2001). Vegetation carbon storage and density of forest ecosystems in China. Chinese Journal of Applied Ecology, 12, 13-16. (in Chinese with English abstract) [王效科, 冯宗炜, 欧阳志云 (2001). 中国森林生态系统的植物碳储量和碳密度研究. 应用 生态学报, 12, 13-16.]

Wiesmeier M, von Luetzow M, Spoerlein P, Geuss U, Hangen E, Reischl A, Schilling B, Koegel-Knabner I (2015). Land use effects on organic carbon storage in soils of Bavaria: The importance of soil types. Soil and Tillage Research, 146, 296-302.

Wu QB, Wang XK, Duan XN, Deng LB, Lu F, Ouyang ZY, Feng ZW (2008). Carbon sequestration and its potential by forest ecosystems in China. Acta Ecologica Sinica, 28, 517-524. (in Chinese with English abstract) [吴庆标, 王 效科, 段晓男, 邓立斌, 逯非, 欧阳志云, 冯宗炜 (2008). 中国森林生态系统植被固碳现状和潜力. 生态 学报, 28, 517-524.]

Xie XL, Sun B, Zhou HZ, Li ZP (2004). Soil carbon stocks and their influencing factors under native vegetations in China. Acta Pedologia Sinica, 41, 687-699. (in Chinese with English abstract) [解宪丽, 孙波, 周慧珍, 李忠佩 (2004). 不同植被下中国土壤有机碳的储量与影响因子. 土壤学报, 41, 687-699.]

Xu JD (2014). The 8th Forest Resources Inventory Results and Analysis in China. Forestry Econmics, (3), 6-8. (in Chinese with English abstract) [徐济德 (2014). 我国第八次 森林资源清查结果及分析. 林业经济, (3), 6-8.]

Xu WQ, Yang L, Chen X, Gao YQ, Wang L (2016). Carbon storage, spatial distribution and the influence factors in Tianshan forests. Chinese Journal of Plant Ecology, 40, 364-373. [许文强, 杨辽, 陈曦, 高亚琪, 王蕾 (2016).
天山森林生态系统碳储量格局及其影响因素. 植物生 态学报, 40, 364-373.]

Ye JS, She GH (2010). Forest carbon dynamics in Guangdong Province. Journal of Nanjing Forestry University (Natural Science Edition), 34(4), 7-12. (in Chinese with English abstract) [叶金盛, 余光辉 (2010). 广东省森林植被碳 储量动态研究. 南京林业大学学报(自然科学版), 34(4), 7-12.]

Zhang CH, Ju WM, Chen JM, Zan M, Li DQ, Zhou YL, Wang XQ (2013a). China's forest biomass carbon sink based on seven inventories from 1973 to 2008. Climatic Change, 118, 933-948.

Zhang H, Guan DS, Song MW (2012). Biomass and carbon storage of Eucalyptus and Acacia plantations in the Pearl River Delta, South China. Forest Ecology and Management, 277, 90-97.

Zhang YD, Gu FX, Liu SR, Liu YC, Li C (2013b). Variations of carbon stock with forest types in subalpine region of southwestern China. Forest Ecology and Management, 300, 88-95.

Zhao M, Zhou GS (2004). Carbon storage of forest vegetation and its relationship with climatic factors. Scientia Geographica Sinica, 24, 50-54. (in Chinese with English abstract) [赵敏, 周广胜 (2004). 中国森林生态系统的 植物碳栬量及其影响因子分析. 地理科学, 24, 50-54.]

Zhou YR, Yu ZL, Zhao SD (2000). Carbon storage and budget of major Chinese forest types. Acta Phytoecologica Sinica, 24, 518-522. (in Chinese with English abstract) [周玉荣, 于振良, 赵士洞 (2000). 我国主要森林生态系统碳咜量 和碳平衡. 植物生态学报, 24, 518-522.]

特邀编委: 李胜功 责任编辑: 李 敏

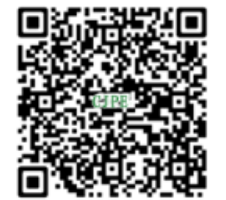

植物生态学报官网 唯一投稿网址

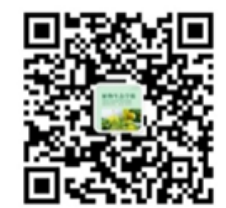

微信订阅号

期刊及学科 相关信息发布

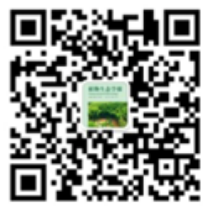

微信服务号

稿件状态查询 全文检索浏览 